\title{
Bank Monitoring Incentives and Borrower Earnings Management: Evidence from the Japanese Banking Crisis of 1993-2002
}

Gil S. Bae, Yasushi Hamao, and Jun-Koo Kang*

This version: March 2009

* Bae is from Korea University (Tel.: +822-3290-1951, Fax: +822-925-4035, E-mail: gilbae@korea.ac.kr), Hamao is from University of Southern California (Tel.: +1-213-740-0822, Fax: +1-310-450-5875, Email: hamao@usc.edu), and Kang is from Nanyang Technological University and Michigan State University (Tel.: +65-6790-5662, Fax: +65-6791-3697, E-mail: jkkang@,ntu.edu.sg, kangju@msu.edu). We are grateful for comments from Bok Baik, Ted Fee, Wayne Ferson, Lawrence Harris, Naveen Khanna, Wei-Lin Liu, Kevin Murphy, Joe Peek, Josh Pierce, Yishay Yafeh, Han Sang Yi, and seminar participants at City University of Hong Kong and University of Southern California. We thank especially Harry DeAngelo and René Stulz for their insightful comments. 


\title{
Bank Monitoring Incentives and Borrower Earnings Management: Evidence from the Japanese Banking Crisis of 1993-2002
}

\begin{abstract}
We examine banks' disincentives to monitor borrower earnings management activity during the Japanese banking crisis of 1993-2002. We show that during this period, a period characterized by significant deterioration in the financial health of the Japanese banking sector, firms that borrow a large amount of short-term loans from their main bank manage earnings more aggressively around public equity offerings. This result derives largely from the subsample of offerings by poorly performing firms that maintain lending relationships with main banks that are in weak financial health. We also find a significant decrease in post-offering short-term lending by the main banks for firms that manage earnings upward prior to the offerings. In contrast, we do not find such results during the boom period of 1983-1992. Our results suggest that, when they are under great pressure for survival, Japanese main banks have few incentives to monitor corporate managers, and act primarily in the interests of short-term creditors.
\end{abstract}

Key words: Main banks, Short-term creditors, Monitoring, Lending relationship, Public equity offerings, Earnings management, Discretionary current accruals. 
The banking literature emphasizes the positive role of banks in providing client firms valuable monitoring functions (Ramakrishnan and Thakor (1984), Fama (1985), Sharpe (1990), Diamond (1984, 1991)). Banks provide loans and diverse financial services to firms with which they have an ongoing relationship. This continuous and stable bank-firm relationship allows the bank to acquire information about the borrowing firm and gives the bank a competitive advantage in monitoring the firm. As such, a bank can reduce client firms' informational asymmetry and managerial incentive problems.

However, it is not clear whether banks always perform a valuable monitoring function for their client firms, particularly when they experience large negative shocks. Banking shocks may affect banks' incentives to monitor borrowing firms for several reasons. For example, during a banking crisis, banks are usually saddled with large amounts of bad loans and the bank regulatory authority is likely to require troubled banks to set aside more capital against their expected future loan losses. These bad loan problems and additional capital requirements can create incentives for banks to take actions that preserve their claims on borrowers rather than take actions that maximize borrower value. As the 1997-1998 Asian financial crisis demonstrated, bad loan problems can also influence banks to engage in the misallocation of credit. For instance, in tightening the credit available to unhealthy borrowers, banks may decide to curtail lending to risky firms with good future prospects. Alternatively, banks may decide to continue lending to financially weak borrowers since doing so tends to make the bank's balance sheet look better and enables borrowers to make interest payments on outstanding loans (Peek and Rosengren (2005)). This misallocation of bank credit in turn forces firms to make suboptimal investment decisions such as passing up positive net present value projects, delaying needed restructuring, and engaging in asset substitution.

In addition to these perverse incentives faced by banks, during a banking crisis, banks are not likely to have enough resources to monitor their client firms, further creating banks' disincentives to assume the role of the active monitor. Holmstrom and Tirole (1997) argue that the intensity of monitoring by financial institutions is positively related to the amount of their capital invested in client firms 
(monitoring capital) relative to firm capital. To the extent that during a banking crisis monitoring capital is scarcer than firm capital and loan losses and asset price deflation significantly reduce the equity of the banking sector, Holmstrom and Tirole's (1997) argument suggests that bank monitoring is less likely to be intense during a banking crisis than during a non-crisis.

In this paper we examine banks' incentives to monitor corporate managers using the Japanese banking crisis during the 1990s as the research setting. Specifically, using earnings management around public equity offerings by Japanese firms as a measure for managerial opportunistic behaviors, we investigate how banks' incentives (disincentives) to monitor corporate opportunistic behavior differ during two distinct economic conditions, the boom period (1983 - 1992), during which Japanese banks aggressively increased lending to the corporate sector, and the crisis period (1993 - 2002), during which the Japanese economy experienced a significant deterioration in the financial health of the banking sector. ${ }^{1}$

Our focus on Japanese banks is motivated by two factors, namely, the importance of bank relationships in Japan and the difficulties of the Japanese banking sector in the 1990s. First, unlike in the U.S., many Japanese firms obtain a substantial fraction of their debt financing from a single commercial bank that is their main bank (Aoki, 1990). ${ }^{2}$ Moreover, whereas the Glass-Steagall Act of 1933 precludes U.S. banks from owning stocks, Japanese banks are allowed to invest in the equity of other companies. Admati and Pfleiderer (1994) consider a manager who has an incentive to continue projects even when it is optimal to terminate them. They show that such suboptimal decision can be avoided with a presence of an informed creditor with a fixed fraction claim, such as equity. Admati and Pfleiderer (1994) suggest that Japanese banks represent an example of such informed investors. Kang and Stulz (1996) also view

\footnotetext{
${ }^{1}$ Teoh, Welch, and Wong (1998) and Rangan (1998) find that in the U.S., firms that conduct seasoned equity offerings manage earnings through accounting accruals, and that subsequent earnings and stock return underperformance are correlated with the level of earnings management during the equity issuance period. Erickson and Wang (1999) and Louis (2004) also report evidence consistent with pre-merger earnings management by acquiring firms, particularly stock-for-stock acquirers. These results suggest that acquirers engage in earnings management in order to inflate their stock prices and thus reduce the exchange ratio.

${ }^{2}$ Sometimes this main bank relation is part of a group network, or keiretsu, although firms that do not belong to a keiretsu also maintain ties to a main bank.
} 
that the long-term investors in Japan such as banks are like the fixed-fraction investors analyzed in Admati and Pfleiderer (1994). In a similar vein, Jensen (1989) argues that the joint ownership of debt and equity claims by informed investors results in stringent managerial monitoring and creates strong incentives for managers to make value-maximizing decisions. These studies suggest that the role of banks in corporate governance is more important in Japan than in the capital market-based system of the U.S. (Aoki (1990), Hoshi, Kashyap, and Scharfstein (1991), Kaplan (1994), Kaplan and Minton (1994), Kang and Shivdasani (1995)). Consequently, should the effect of bank monitoring on corporate earnings management exists, it is more likely to surface in Japan than in a capital-market-based system such as the U.S. Second, in the early 1990 s the Japanese banking sector started to face considerable problems limiting its ability to renew loans or extend new loans to firms. These bank difficulties were of a scale that even Long Term Credit Bank of Japan, which was the 9th largest bank in the world, collapsed in 1998. Thus, the difficulties in the Japanese banking sector during the 1990s, together with Japan's close bank-firm ties, make Japan a good testing ground for investigating how the changing economic conditions affect banks' incentives to monitor corporate managers.

We posit that although the main bank as a monitor generally has strong incentives to discourage the opportunistic financial reporting behavior of equity-issuing borrowers prior to an offering, ${ }^{3}$ it does not have such incentives during a banking crisis, possibly due to its desire to preserve its claims on borrowers. Ahn and Choi (2009) argue that the extent of borrower earnings management is directly related to the qualitative measure of credit risk (i.e., the competency of a borrowing firm's management and the reliability of its financial statements). For example, the higher the borrower's income-increasing accrual management is, the lower the quality of management becomes. The borrower that engages in aggressive accrual management is also likely to have lower quality earnings. Since these lower management and earnings qualities have an adverse effect on borrower credit risk, banks as creditors should have strong incentives to monitor diligently for borrower income manipulation. However, during

\footnotetext{
${ }^{3}$ Supporting this view, Ahn and Choi (2009) show that a borrowing firm's earnings management in the U.S. deceases as the magnitude of a bank loan increases.
} 
a crisis, a borrower's ability to generate sufficient cash flow to repay the loan's principal and interest becomes a critical concern for the bank. Thus, the main bank faced with regulatory requirements to set aside more capital has incentives to engage in opportunistic behaviors in order to avoid classifying their existing loans as nonperforming or to accumulate more cash reserves for future adverse events. Equity offerings improve a firm's cash position, which in turn, improves the firm's ability to service its debt. Consequently, during a crisis, the main bank that wants to protect its loan claims will have few incentives to discourage the borrower's income-increasing reporting activity prior to an offering since such activity inflates the offering price and thus increases the proceeds from the offering.

Moreover, during a crisis, banks tend to attach a low value to their reputational capital or do not have enough resources to monitor their client firms, creating additional disincentives to monitor firms.

Consistent with results that correspond to the U.S., we find significant earnings management around public equity offerings in Japan, but with a large cross-sectional variation. The regression analysis shows that during 1993-2002, firms that borrow a large amount of short-term loans from their main bank manage earnings more aggressively around public equity offerings. This result derives largely from the subsample of offerings by poorly performing firms that maintain lending relationships with main banks that are in weak financial health. In contrast, we do not find such results during the boom period of 19831992. We also find that during a banking crisis, there is a significant decrease in post-offering short-term lending by the main banks for firms that manage earnings upward prior to the offerings. This result, together with those of Peek and Rosengren (2005), suggests that during a banking crisis, Japanese banks allocate less credit to borrowers that are still economically viable (i.e., borrowers that are able to issue equity and thus might be better clients for banks) and more credit to troubled borrowers. Overall, these results suggest that Japanese main banks act to maximize its interests as short-term creditors when they are under great pressure for survival.

We perform several robustness checks on our tests. In particular, we evaluate endogeneity of the main bank relationship, a firm's motive to diversify financing sources, and regulatory rules concerning 
public equity offerings in our sample period. The results are qualitatively unchanged. In addition, we find that abnormal accruals are not significantly related to abnormal offering announcement returns, suggesting that outside investors in Japan do not see through issuing firms' attempts to engage in earnings management.

Our paper makes an important contribution to the literature by providing evidence on the governance role of informed creditors during a banking crisis. Unlike previous studies that explore the benefits of close bank relationships (Fama (1985), Diamond (1991), Hoshi, Kashyap, and Scharfstein (1991), Kaplan (1994), Kaplan and Minton (1994), Kang and Shivdasani (1995)), we focus on the dark side of bank relationships (Sharpe (1990), Rajan (1992), Slovin, Sushka, and Polonchek (1993), Gibson (1995), Weinstein and Yafeh (1998), Morck and Nakamura (1999), Kang and Stulz (2000)) and show how banks' incentives to monitor the firms are different during boom and crisis periods. Our work therefore extends the previous literature that evaluates the role of banks in corporate governance and sheds light on the debate regarding this role.

The paper proceeds as follows. In Section I, we develop the hypotheses to be tested. In Section II, we explain our measures of earnings management. Section III describes the data and sample characteristics and Section IV presents the empirical results. Additional robustness tests are reported in Section V. Section VI summarizes and concludes the paper.

\section{Hypothesis development}

The core of the Japanese corporate governance system consists of main banks. Japanese firms typically obtain a substantial fraction of their debt financing from a single commercial bank, their main bank. The main bank also provides the firm diverse financial services and helps it access capital markets by providing financial guarantees. In addition, the main bank monitors the firm's management and intervenes at times of poor performance (Hoshi, Kashyap, and Scharfstein (1990), Sheard (1994)), sometimes sending directors to the firm's board to help the firm improve its performance (Kaplan (1994), 
Kaplan and Minton (1994), Kang and Shivdasani (1995)). These intermediary functions performed by the main bank suggest that the main bank alleviates firms' managerial incentive problems and eases capital constraints that financially unhealthy firms face in the market.

However, it is not entirely clear whether main banks always perform these valuable functions for their client firms, particularly when the banking sector experiences a severe exogenous shock. As Sharpe (1990) and Rajan (1992) note, close lending relationships enable banks to exercise significant influence over, and thereby expropriate rents from, borrowing firms. For example, as firms work more closely with banks, they may find it harder to raise funds through other means of public financing and thus may be more vulnerable to being "held up" by the banks. Supporting this view, Weinstein and Yafeh (1998) show that firms closely related to Japanese banks do not show higher profitability or faster growth rates than their industry peers, and they pay relatively high interest rates on their bank loans.

This so-called hold-up problem can be particularly severe during a banking crisis period. When banks suffer from an exogenous shock and are forced to tighten credit, they become more concerned about the capacity of borrowers to generate sufficient future cash flow to repay the principal and interest on their loans, as the inability of borrowers to service their debt can have a significantly negative effect on a bank's credit risk and cost of capital. As a result, during a crisis banks are better off if their client firms with impending financial problems issue equity and use the offering proceeds to repay their loan obligations. Furthermore, managers of equity issuing firms have incentives to manage earnings upward around equity offerings to maximize the proceeds from the sale (Teoh, Welch, and Wong (1998), Rangan (1998)). During a crisis banks may have fewer incentives to monitor the issuer's income-increasing accrual management, as high reported earnings at the time of equity offerings inflate the offer price and thus increase the offering proceeds, which provide banks additional capital with which to buffer themselves against a borrower's financial difficulties. ${ }^{4}$

\footnotetext{
${ }^{4}$ Japanese main banks are expected to be familiar with firms' accrual choice decisions because of several reasons. For example, as the largest debtholder the main bank may have a competitive advantage over other capital market participants in collecting private information about the borrowing firms. Moreover, it is not unusual for Japanese 
In addition to this perverse incentive of banks, banks have fewer resources to monitor the borrowers during a crisis. Holmstrom and Tirole (1997) argue that the intensity of monitoring by financial institutions varies depending on the relative amount of their monitoring capital invested in borrowers and it is less when such capital gets scarcer, suggesting that banks have disincentives to monitor their borrowers when the whole banking sector is experiencing difficulties.

Moreover, since a large portion of bank loans in Japan are short-term loans ${ }^{5}$ and main banks usually have the largest debt claim on their client firms' assets, main banks have additional incentives to welcome increases in offering proceeds and act in the interests of short-term creditors.

Although high reported earnings that result from income-increasing accrual management around the offerings may allow firms to issue equity at higher prices (Kim and Park (2005)), such accrual management also entails costs. For example, if it is detected, the issuer could suffer loss of investor confidence, regulatory intervention and possibly jeopardize the equity issuance. In addition, the issuer could be sued (DuCharme, Malatesta, and Sefcik (2004), Gong, Louis, and Sun (2008)). Even if the earnings management is undetected prior to the issuance, there should be downward pressure on stock prices after the issuance unless the earnings management is maintained. During a banking crisis period, however, equity issuing firms, particularly those with higher short-term loans, may pay less attention to such costs because these firms are likely to face fewer interventions from their banks due to banks'

firms to have representatives from their main bank on their boards. Kroszner and Strahan (2001), for example, show that firms with an executive of their main bank on their board account for $42.8 \%$ of the 761 large firms listed on the Tokyo Stock Exchange (TSE) in 1992, whereas the corresponding number for large U.S. firms is only 5.8\%. Kaplan and Minton (1994) and Kang and Shivdasani (1995) show further that Japanese main banks send directors to a client firm's board in periods of financial distress. Similarly, Morck and Nakamura (1999) find that the appointments of bank executives to the boards of Japanese firms outside bank groups are precipitated largely by liquidity crises. Because the board of directors is responsible for the preparation and presentation of financial reports, main bank representatives on boards could have significant information on borrowing firms' accrual choice decisions. Finally, the Association of Bank Loan and Credit Officers (Robert Morris Associates) suggests that in some cases, and especially in the case of a permanent capital loan, banks require borrowers to provide a listing of account receivables together with their aging information so that they can examine the appropriateness of the receivables' values (Choi (2005)). Banks also examine whether loans are fully covered by receivables. To the extent account receivables are an important determinant of accounting accruals, banks' oversight over receivables may allow banks to be familiar with client firms' accruals decisions.

${ }^{5}$ For non-financial and non-utility firms listed on the Tokyo Stock Exchange in 2002, the last year of our sample period, short-term bank loans with maturity less than one year on average account for $66.6 \%$ of total bank loans, with a median of $69.8 \%$. 
disincentives to monitor. Moreover, they face greater financial distress risk due to their higher short-term leverage, which incentivizes them to raise larger capital to reduce financial distress risk. These arguments lead to the following hypothesis:

H1. During a banking crisis period, firms with close ties to their main bank, as measured by the ratio of loans from the main bank to the firm's total debt (the "main bank loan ratio"), are more likely to increase reported earnings prior to equity offerings. Consequently, the main bank loan ratio is positively related to the extent of earnings management by equity-issuing firms. This positive effect is expected to be more pronounced for short-term main bank loans than for long-term main bank loans.

We also expect that the disincentives faced by the main bank to monitor earnings management during a crisis are stronger when the main bank is financially weaker. Since the adverse effect of future loan losses on investors' expectations of the quality of a bank's loan portfolio is particularly severe for financially weak banks, these banks may have fewer incentives to monitor issuer accrual management in order to increase the proceeds from the offerings. Furthermore, compared to healthy banks, unhealthy banks may place less value on their reputational capital and have fewer resources to monitor issuer opportunistic behavior. To the extent that the incentives for earnings overstatement are also particularly strong for the troubled firms themselves, we expect this disincentive effect to be even more pronounced for poorly performing firms. These arguments lead to our second hypothesis:

H2. During a banking crisis, poorly performing firms engage in more aggressive income-increasing earnings management if they maintain lending relationships with poorly performing or high-risk main banks.

If the bank's private information produces unbiased forecasts of client issuers' future prospects, the 
bank is more likely to be quiet about earnings management activity by the issuers about which it has unfavorable information. To the extent that these issuers engage in more aggressive earnings management and that the bank has strong incentives to require such issuers to repay its loans, issuers with a higher level of earnings management around the offering are expected to experience larger declines in loans from their main bank after the offerings. Alternatively, given the finding that Japanese banks continued lending to poorly performing firms during the crisis period (Peek and Rosengren (2005)), to provide required credit to these firms, Japanese banks might have strong incentives to reduce credit to firms that can raise capital on their own. Since firms that engage in aggressive earnings management, if not detected, are more likely to be successful in raising new capital in the stock market, we expect these firms to experience a larger post-offering loan decline. Thus, our third hypothesis is:

H3. Main bank lending declines after the offerings substantially more for firms that manage earnings aggressively prior to the offerings. This effect is more pronounced during the banking crisis.

While we are not aware of any previous studies on bank-firm relationships that investigate this particular type of conflict, the above lines of reasoning are similar to those of studies that examine the impact of a deterioration in bank durability on the value of borrowers. For instance, Slovin, Sushka, and Polonchek (1993) examine the effect of the near failure of Continental Illinois Bank and its subsequent rescue by the Federal Deposit Insurance Corporation (FDIC) on client firm value and find that the bank's impending insolvency (subsequent rescue) had negative (positive) effects on client firms' share prices. Gibson (1995) examines whether the health of the Japanese main bank influences the investments of client firms. He shows that a firm with a low-rated main bank (AA-) invests $30 \%$ less than a firm with a high-rated main bank (AA+). In a similar vein, Kang and Stulz (2000) show that Japanese firms that borrow more from banks suffer larger drops in stock prices and cut investments back more substantially during the 1990 to 1993 period. Finally, focusing on client firms' stock market performance, Brewer, 
Genay, Hunter, and Kaufman (2003) find that firms with greater access to alternative sources of funding experience a less severe adverse impact following the announcement of bank failure, whereas Miyajima and Yafeh (2007) document that high leverage, low tech, and low market-to-book firms are the most affected by malaise in the banking sector. These results imply that a reduction in bank durability has an adverse impact on both the value and the investment policy of borrowers.

\section{Measuring earnings management}

Earnings consist of actual cash flows and accruals. Accruals are accounting adjustments to the firm's cash flow from operations that are designed to help convey information about the firm's true economic performance that is not always reflected in current cash flows. Accrual adjustments depend on the firm's business environment and management's assessment of the magnitude and timing of actual economic events. For example, firms have discretion over the choice of estimates for uncollectibles (bad debts), the choice of estimates for write-offs of inventory and fixed assets, and the choice of depreciation policies. Using this discretion, managers may manipulate accruals to convey a distorted view of the firm's future prospects. Prior research shows that accounting accruals are affected by agency issues and asymmetric information. ${ }^{6}$

If managers use discretion to influence market perceptions, we expect "discretionary" accruals to systematically reflect the managerial intention. To measure discretionary accruals, we use the modified Jones model proposed by Dechow, Sloan, and Sweeney (1995), as it is known to be the most powerful model in detecting earnings management among the competing models. Specifically, we first regress current accruals on the difference between the change in sales revenue and the change in accounts receivable. The cross-sectional regression is performed for each fiscal year in the test period using all non-issuing firms in the same two-digit industry code. The estimated coefficient on the difference term is then used to calculate the expected accruals of the equity-issuing firms. The residual after subtracting

\footnotetext{
${ }^{6}$ Healy and Wahlen (1999) provide a comprehensive review of earnings management research.
} 
expected accruals from reported accruals is excess accruals.

Kothari, Leone, and Wasley (2004) show that discretionary accruals adjusted for a performancematched firm's discretionary accruals, where the match is based on a firm's industry membership and current-period return on assets, tend to be the best-specified measure of discretionary accruals across a wide variety of simulated event conditions. Following Kothari, Leone, and Wasley (2004), we subtract the discretionary accruals of a matching firm from those of a sample firm. We interpret matching firmcontrolled discretionary accruals (hereafter, "adjusted discretionary current accruals") as a proxy for accruals manipulation. $^{7}$ (See the Appendix for a detailed discussion on our method of measuring discretionary current accruals.)

\section{Data and sample description}

Our sample consists of Japanese firms that issued public equity in domestic markets between 1983 and 2002. We identify an initial sample of issuing firms from the Tokyo Stock Exchange Annual Securities Statistics. We cross-reference and supplement this sample with data from Thomson Financial Securities data and NEEDS corporate finance-related data. We eliminate firms belonging to either the financial services or utilities industries. We also eliminate those firms that issued multiple classes of securities within three years prior to or subsequent to the offering, to avoid obtaining results confounded by multiple issues that cluster during our analysis period. ${ }^{8}$ Finally, if a firm issued equity more than once within a six-year period, we retain the first issue in our sample. These screens yield a final sample of 508 public issues. We obtain stock price and financial data on the issuing firms from the Pacific-Basin

\footnotetext{
${ }^{7}$ Following Rangan (1998), Louis (2004), and Darrough and Rangan (2005), we use adjusted discretionary current accruals as our primary measure of earnings management throughout the paper. In untabulated tests, we repeat all analyses using adjusted discretionary total accruals as a measure of earnings management and find that our results do not change. When we use total accruals as a measure of earnings management, we include in equation (a1) in the Appendix the gross level of property, plant, and equipment scaled by total assets in the beginning of the year as an additional explanatory variable. Nondiscretionary total accruals in equation (a2) in the Appendix are also computed with this additional variable in the model.

${ }^{8}$ Multiple issues include those offerings in which a firm issues the same (or different) types of securities both privately and publicly, or in which a firm issues the same (or different) types of securities both in Japan and in overseas markets. Since the managerial incentives to issue private or domestic securities are likely to be different from those to issue public or foreign securities, we exclude multiple issues from our analyses.
} 
Capital Market (PACAP) Research Center database. We collect data on a firm's bank borrowings from various issues of Kigyo Keiretsu Soran, a comprehensive guide to Japanese firms published by Toyo Keizai, and supplement this information with NEEDS Bank Loans data.

We divide our sample period into two subperiods, the pre-crisis period (1983-1992) and the crisis period (1993-2002). The rationale for using 1993 to delineate the beginning of the banking crisis is as follows. ${ }^{9}$ Before the banking crisis, Japanese banks aggressively increased lending to the corporate sector; for example, according to Bank of Japan statistics, the aggregate loan balance to GDP ratio for Japanese banks rose from $77 \%$ in 1982 to $105 \%$ in 1989 . However, after the Nikkei 225 index and land prices hit their highest levels at the end of 1989 and the beginning of 1991, respectively, both stock and land prices started to fall as rapidly as they had gone up, ending the economic boom of the "asset bubble" period. With the economic slowdown, many of the loans made during the previous boom period turned out to be nonperforming and the resulting credit losses badly hurt bank balance sheets and bank credit availability (Hickock and Osler (1994)). Japanese banks and regulatory authorities, however, were slow in recognizing the seriousness of the consequences of the bursting of the bubble. For instance, facing the nonperforming loan problem, Japanese banks only started to shrink their loan portfolios in $1993 .{ }^{10}$ Similarly, it was March of 1993 when Japanese banks were first required to disclose nonperforming loans, which were defined rather narrowly. Regulators made several revisions to the rules on the classification of nonperforming loans in the following years, increasing nonperforming loans disclosed by banks dramatically from 3\% of total loans in 1993 to $8 \%$ of total loans in 2002 . Fukao (2003) argues that the amount of properly classified bad loans could be more than twice as large as the amount of bad loans publicly reported by individual banks. ${ }^{11}$

\footnotetext{
${ }^{9}$ Peek and Rosengren (2005) also use 1993 as the start of their sample period.

${ }^{10}$ Also in 1993, the Basel Accord risk-based capital requirement was implemented in Japan. The requirement that banks disclose nonperforming loans marks the end of the period of complete denial by banks, as its implementation forced banks to quickly address the impending problem of their nonperforming loans. This suggests that banks likely had different incentives in managing existing loans to client firms before and after the disclosure requirement.

${ }^{11}$ In untabulated tests, we define the crash period from 1990 to 2002 and obtain results that are qualitatively similar to those reported in the paper.
} 
Table I shows the distribution of equity offerings by year and by industry. The table indicates a substantial decline in the frequency of public issues during the early part of the crisis period, with only 16 issues in the years 1993,1994, and 1995. A breakdown of the sample by industry shows that most of the issuing firms are in manufacturing (306 issues), wholesale and retail (103 issues), and construction (34 issues).

Table II presents descriptive statistics for our sample of issuing firms. We measure firm-specific variables at the fiscal year-end that is immediately before the issue date. The mean and median market values of equity are 130.5 billion yen and 37.1 billion yen, respectively. The median issue amount is 3.7 billion yen and the median ratio of issue amount to market value of equity is $8.8 \%$. We measure past operating performance of an issuing firm by the ratio of operating income to total assets and find that the median ratio is $6.2 \%$. The issuer's median excess stock return relative to the market over the past one year is $6.3 \%$, and the mean and median leverage (debt / total assets) ratios are $65.4 \%$ and $68 \%$, respectively. Finally, the median Tobin's q (sum of book value of debt and market value of equity / total assets) is 1.75 . This number, together with the ratio of operating income to total assets and past marketadjusted excess returns, suggest that many of our sample firms perform well before the equity issue.

Table II also reports summary statistics on sample firms' borrowing activities. Defining the bank loan ratio as the ratio of a firm's total borrowings from banks to total debt, we find that it averages $25.4 \%$. The mean and median ratios of short-term (long-term) bank loans with maturity less (longer) than one year to total debt are $15.7 \%(9.6 \%)$ and $14 \%(5.8 \%)$, respectively, suggesting that short-term loans account for a more significant portion of debt financing of Japanese firms. Similar to the bank loan ratio, we compute the main bank loan ratio as the ratio of a firm's total borrowings from its main bank to total debt. Following Hoshi, Kashyap, and Scharfstein (1990) and Aoki, Patrick, and Sheard (1994), we define the main bank as the firm's largest lender. ${ }^{12}$ Borrowings from the main bank on average account for $8.9 \%$ of

\footnotetext{
${ }^{12}$ In rare occasions, two banks are tied as the largest lenders. In these cases, we examine shareholding by banks and existence of board members who were originally from banks, and identify the bank with the strongest relationship as the main bank.
} 
total debt and short-term (long-term) main bank loans on average account for 5.3\% (3.6\%) of total debt. We find similar patterns for other bank loans.

Next, Table II reports on sample firms' ownership distribution. The mean equity ownership positions of financial institutions, other corporations, and foreign investors are, respectively, $27.5 \%, 31.8 \%$, and 5.2\%. We identify each firm's affiliation to a keiretsu using Kigyo Keiretsu Soran and Nikkei Company Handbook. We consider firms as being a member of a keiretsu if they belong to any of the six bankcentered keiretsu (Mitsubishi, Mitsui, Sumitomo, Fuyo, DKB, and Sanwa). According to this classification, $18.7 \%$ of our sample firms belong to a keiretsu.

Finally, Table II presents information on the financial condition of the main banks of our issuing firms. Since some firms have no bank borrowing (hence no main bank) and some main banks are not listed on the stock exchange, we conduct our tests employing these variables over a smaller sample of 404 firms. The mean (median) ratio of past operating income to total assets is $0.4 \%(0.5 \%)$. The mean (median) excess stock return relative to the market over the past one year is $-0.04 \%(-11.3 \%)$ and the median is significant at the 0.01 level. Although our sample main banks perform poorly on average during the sample period, it should be noted that there is large cross-sectional variation in their performance. The standard deviation of past operating income to total assets and the standard deviation of past cumulative excess returns are $0.5 \%$ and $31.6 \%$, respectively. We also measure bank health using Tobin's $\mathrm{q}$ and find that it averages 1.1. Finally, we measure the risk of main banks as the standard deviation of the ratio of operating income to total assets over the past ten years and find that it averages $0.2 \%$.

\section{Empirical results}

\section{A. Abnormal accruals}

Several studies show that managers of U.S. firms take abnormally large discretionary accruals during the periods surrounding public equity issuances in order to increase reported earnings (Teoh, Welch, and 
Wong (1998), Rangan (1998), Shivakumar (2000), Anthony, Bettinghaus, and Farber (2005)). In this section, we examine whether managers of Japanese firms also manage earnings around public equity offerings.

Table III presents income from continuing operations scaled by prior-year total assets (ROA), cash flow from operations, current accruals, and adjusted discretionary current accruals for our sample firms in the six years surrounding the issue year. Panel A of Table III presents ROA. The mean ROA shows an improvement in the pre-issue period but a deterioration in the post-issue period; specifically, it is $6.6 \%$ in year -3 , it rises to $7.2 \%$ in year -2 and $8.2 \%$ in year -1 , it peaks in year 0 at $8.6 \%$, and then it shows a monotonic decline from year 1 to year 3. The time-series ROA profiles for our sample of firms conducting public equity issues mirror those of Teoh, Welch, and Wong (1998).

Panel B of Table III reports the cash flow from operations scaled by prior-year total assets, where cash flow from operations is defined as net income less total accruals. The mean cash flow from operations shows an increase from year $-3(9.6 \%)$ to year $-1(10.3 \%)$, and then a decline in year $0(8.3 \%)$. The mean cash flows decline further in year 1 and then remain steady in years 2 and 3 . The medians observe similar patterns. Therefore, new public equity issues in Japan appear to take place when firms experience a deterioration in cash flow from operations.

Panel C of Table III presents current accruals. Current accruals are considerably larger in the year of equity issuance relative to those in other years surrounding the issues. The mean and median current accruals during the pre-issue period are small and not significant. In year 0 , however, the mean and median current accruals increase to $3.3 \%$ and $2.9 \%$, respectively, both of which are significant at the 0.01 level. Current accruals during the post-issue period remain higher than those during the pre-issue period, but continue to decrease from their level in year 0 .

To summarize thus far, we find that firms conduct public equity offerings when net income performance shows improvement but cash flow from operations deteriorates, indicating that managers engage in aggressive management of earnings during the offering year. 
Panel D of Table III presents the time-series profile of industry- and performance-adjusted discretionary current accruals. We find that adjusted discretionary current accruals are highest in the offering year (the mean and median adjusted discretionary current accruals are $2.3 \%$ and $2.2 \%$, respectively) and are significant at the 0.01 level. These results are consistent with those for public equity offerings in the U.S. (Teoh, Welch, and Wong (1998), Rangan (1998)); for example, Teoh, Welch, and Wong (1998) report median (mean) adjusted discretionary current accruals of $2.9 \%$ (4.9\%) in year 0 . We also find that the mean and median adjusted discretionary current accruals in years -3 through -1 are statistically insignificant, and that adjusted discretionary current accruals in post-issue years are generally higher than those in pre-issue years, with the mean adjusted discretionary current accrual in year +1 positive and significant. These results suggest that managers continue to manage earnings after offerings, possibly reflecting the fact that managers try to avoid potential legal liability that would be triggered by an earnings reversal immediately after the offerings.

In untabulated tests we also estimate discretionary accruals using alternative models introduced in the recent literature. In particular, following Anthony, Bettinghaus, and Farber (2005), we estimate the industry- and performance-matched discretionary current accruals using the following three models:

Model 1: $\quad C A C_{i t} / T A_{i t-1}=\beta_{0}+\beta_{1} \Delta R E V_{i t} / T A_{i t-1}+\varepsilon_{i t}$

Model 2: $\quad$ CAC $_{\text {it }} /$ TA $_{\text {it }-1}=\beta_{0}+\beta_{1} /$ TA $_{\text {it }-1}+\beta_{2} \Delta R E V_{i t} /$ TA $_{\text {it }-1}+\beta_{3}$ FSALESGROWTH $_{i t} /$ TA $_{\text {it }}-1$ $+\beta_{4} C A C_{i t-1} / T A_{i t-2}+\varepsilon_{i t}$

Model 3: $\quad C A C_{i t} / T A_{i t-1}=\beta_{0}+\beta_{1} / T A_{i t-1}+\beta_{2}\left(\triangle R E V_{i t}-\triangle R E C_{i t}\right) / T A_{i t-1}$ $+\beta_{3}$ FSALESGROWTH ${ }_{i t} /$ TA $_{i t-1}+\beta_{4} C A C_{i t-1} / T A_{i t-2}+\varepsilon_{i t}$

where FSALESGROWTH ${ }_{\mathrm{it}}$ represents future sales growth. The definitions of the other variables are the same as those in equation (1). Model 1 is the original Jones model with no scaled intercept. In models 2 and 3, a scaled intercept is added along with two additional variables, namely, future sales growth and lagged current accruals. Because growth firms are likely to increase their current accruals in anticipation of future sales, the Jones model may be misspecified for those firms. To control for this problem we include future sales growth proxied by the change in one-year-ahead sales scaled by total assets in year $t-$ 
1 in models 2 and 3 (Dechow, Richardson, and Tuna (2003)). With respect to current accruals, this variable comprises items that might reverse in the future and thus it is possible that current accruals may reverse within one year. To take this possibility into account, we also include lagged current accruals (CAC of year $t-1)$ in models 2 and 3 . In each of these models, the discretionary current accruals are computed as the difference between realized current accruals scaled by total assets in year $t-1$ and expected accruals estimated using the respective models, where the coefficients are estimated every year for each industry. We find that our results for adjusted discretionary current accruals are reasonably robust to the differences in model specifications used.

Overall, these results suggest that adjusted discretionary current accruals increase abruptly in the year of public equity offerings, which is consistent with the view that issuing firms deliberately engage in income-increasing earnings management in order to inflate reported earnings.

Note that the Nikkei 225 index more than quadrupled from 1983 to 1989 and then lost the substantial gains it had made. To the extent that during a stock market boom, managers of firms that issue equity have stronger incentives to take advantage of overpricing by selling stocks to optimistic investors, their incentives to manipulate earnings may be particularly strong when the stock market experiences large positive returns. To address this issue, in Panel A of Table IV we separate our sample into stock market boom (1983-1989) and bust (1990-2002) periods and present mean and median adjusted discretionary current accruals in the offering year by subperiod. We find that the mean and median abnormal accruals during the bust period are not significantly different from those during the boom period. Thus, positive and significant abnormal accruals during our sample period are not likely to be affected by the overvaluation of the stock market.

To pursue further the argument that the income-increasing earnings management we document in Table III is the result of possible irrational exuberance during the 1980s, in Panel B of Table IV we report mean and median adjusted discretionary current accruals in the offering year by industry. To the extent that the Japanese bubble in the 1980s was largely due to a dramatic increase in land prices (Hickock and 
Osler (1995)), one might expect the effect of the bubble on earnings management to be more manifest in industries in which real estate plays an important role, such as construction and real estate. However, the results in Panel B show that abnormal accruals for firms operating in construction and real estate are relatively small and not significant. These results again suggest that a bubble effect is not the main reason for the positive abnormal accruals during our sample period.

\section{B. Determinants of adjusted discretionary current accruals}

To better understand the cross-sectional variation in accruals for our sample firms, we present the estimates from multivariate regressions. We use the adjusted discretionary current accruals in the offering year as the dependent variable. The regression results are presented in Table V.

In regression (1), we regress the adjusted discretionary current accrual only on the ratio of total bank loans to total debt. We find that adjusted discretionary current accruals are positively and significantly related to a firm's total borrowings from its banks.

In regression (2), we divide total loans into short-term and long-term loans. We find that adjusted discretionary current accruals are positively and significantly related to a firm's short-term borrowings, but are negatively and significantly related to its long-term borrowings. The negative and significant coefficient on long-term borrowings suggests that unlike short-term creditors who have strong incentives to maximize short-term earnings of their client firms, as long-term creditors, main banks perform an important monitoring function in alleviating firms' managerial incentive problems. The result also suggests that long-term debt claim held by the main banks reduces their incentives for myopic behavior and allows them to take a long-term view.

In regression (3), we further divide short-term (long-term) loans into short-term (long-term) loans from the main bank and short-term (long-term) loans from other banks. We find little relation between abnormal accruals and short-term (long-term) loans from other banks, but a significantly positive (negative) relation between abnormal accruals and short-term (long-term) loans from the main bank. The 
regression coefficient on the short-term main bank loan ratio is 0.226 with a $t$-statistic of 2.41 . Evaluating the estimated coefficient at the mean indicates that all else equal, a 10\% increase in the main bank loan ratio results in about a $2.3 \%$ increase in the adjusted discretionary current accruals of issuers. Therefore, the effect of short-term main bank loans on earnings management seems to be both statistically and economically significant. These results suggest that when the main bank lends a large amount of shortterm loans to the firms, it has disincentives to monitor such firms' income-increasing earnings management around equity offerings and thereby benefits its interests as a short-term creditor, supporting the findings of Weinstein and Yafeh (1998) and Morck and Nakamura (1999).

In regression (4), we include the following issue- and firm-specific characteristics as control variables: a keiretsu dummy, ${ }^{13}$ the ratio of the issue amount to the market value of equity, the ratio of operating income to total assets, Tobin's q, ownership structure (equity ownership by financial institutions, equity ownership by other corporations, and equity ownership by foreign investors), firm size (the logarithm of the market value of outstanding equity), and a dummy variable that takes the value of one if the offering is made after 1992. If issue size is relatively small compared to the size of the issuing firm, the economic benefits from earnings management are also expected to be relatively small (Erickson and Wang (1999)). We therefore expect the degree of earnings management to be an increasing function of relative issue size. Next, since poorly performing firms have less ability to service their debt and their equity offerings are less likely to be successful, the incentives to overstate earnings are likely to be particularly strong for these firms. Thus, we expect the extent of earnings management to be more pronounced if issuers experience poor operating performance or have low Tobin's q. Finally, we include ownership structure to control for the monitoring role performed by institutional investors, expecting a negative coefficient on each ownership structure variable. However, existing shareholders might have an

${ }^{13}$ The firms belonging to the same keiretsu often buy and sell goods and services from one another. Furthermore, since keiretsu shareholders seek to keep their stake in the firm constant, they usually participate in new issues. This suggests that keiretsu shareholders serve as long-term investors and thus have incentives to induce firms to choose accounting policies that maximize long-term value over those that temporarily boost short-term earnings, since the value of their transactions with the firm increases as the firm's long-term value increases. 
incentive to support the sale of overpriced equity and thus encourage managers to engage in incomeincreasing earnings management. In this case, we would expect a positive coefficient on ownership.

We find that most of the firm- and issue-specific characteristics have the expected signs, although none of them are significant except for equity ownership by financial institutions, which has a negative and significant coefficient. Controlling for the firm- and issue-specific characteristics does not change the significance of the coefficients on short term and long-term main bank loan ratio variables. In unreported tests, we also control for industry effects, adding six industry dummy variables, and obtain results that are qualitatively similar to those reported in the paper.

In sum, these findings suggest that the distribution of debt claims with a firm's main bank is an important determinant of accounting accruals at the time of an equity offering: main banks do not serve as an active monitor for discouraging misrepresentation of earnings by the issuers to benefit their interests as creditors when their short-term debt claim on issuers account for a significant portion of the issuers' total debt outstanding. ${ }^{14}$

To examine the effect of a main bank's condition on earnings management, in regressions (5) through (8) we employ a subsample of 404 issuers that have main banks. We use four measures of bank condition and compare the abnormal accruals of poorly performing firms associated with poor-quality banks to other types of firms. We partition our sample of main banks into "poor" and "good" by the sample $25^{\text {th }}$ quartiles of their operating income to total assets, market-adjusted cumulative returns during the previous one year, and Tobin's q, and by the sample $75^{\text {th }}$ quartiles of the standard deviation of the ratio of operating income to total assets over the past 10 years. We also separate firms into two groups according to their past operating performance: poorly performing firms comprise those with operating income to total assets smaller than the sample $25^{\text {th }}$ quartile and good performing firms comprise those with operating

\footnotetext{
${ }^{14}$ In untabulated tests, we use a dummy variable that takes the value of one if both the short-term main bank loan ratio and the relative issue size are above their respective sample medians. If the main bank extends a large short-term loan to the issuer prior to its offering and this issuer places a relatively large amount of equity, the economic benefits that the main bank can obtain from earnings management are expected to be large. Thus, the level of abnormal accruals is likely to be high in this case. Consistent with this argument, we find that the coefficient on this dummy variable is 0.023 , with a $t$-statistic of 2.17 , suggesting that issuers with a higher shortterm main bank loan and a larger issue size engage in earnings management more aggressively.
} 
income to total assets greater than the sample $25^{\text {th }}$ quartile. In regression (5), we use an interaction term between a dummy variable for the main bank's poor operating performance and a dummy variable for the firm's poor operating performance. The coefficient on this variable is positive, but not significant. However, when we replace a main bank's past operating performance with a main bank's past stock market performance in regression (6), the coefficient on the interaction term is positive and significant at the 0.05 level. Thus, poorly performing firms manage earnings more aggressively when they maintain lending ties to a main bank with poor stock market performance. This result suggests that weak banks have disincentives to discourage poorly performing issuers to engage in aggressive earnings management in order to increase the proceeds from the offering. However, when we use the standard deviation of the ratio of the main bank's operating income to total assets over the past 10 years and a main bank's Tobin's q as measures of a bank's financial condition in regressions (7) and (8), respectively, the coefficients on the interaction terms are not significant. ${ }^{15}$

Panel B of Table V shows the key results of our paper. To examine whether disincentives faced by banks to monitor the opportunistic financial reporting behavior of equity-issuing borrowers in the offering year are particularly prominent during a banking crisis, we divide our sample into two subperiods, the pre-banking crisis period and the banking crisis period, and re-estimate the full regression separately for each of these two subperiods. We find that the coefficient on the short-term main bank loan ratio is positive and significant only during the banking crisis period. This result supports $H 1$. Furthermore, consistent with $H 2$, during the banking crisis, the coefficient on the interaction term between a dummy variable for poor quality banks and a dummy variable for poorly performing firms is positive and significant, irrespective of the measure of bank condition we use (regressions (9) through (12)). In contrast, none of these variables is significant in the period before the banking crisis. These results

\footnotetext{
${ }^{15}$ Mechanically, firms that have higher accruals are likely to have larger working capital. These firms may need to invest less of their proceeds from equity offerings into working capital and thus are more likely to pay down debt. To address this issue, we include the ratio of working capital to total assets in regressions (1) through (8) and find that its coefficients are not significant. Further, including this variable does not change the significance of the other variables.
} 
suggest that banks' incentives to preserve their claims on borrowers during a crisis and the lack of their monitoring resources provide weak banks strong disincentives to monitor borrower accrual management. We also find that the coefficient on the long-term main bank loan ratio is negative and significant only before the banking crisis, suggesting that during the non-crisis period, the main banks with significant long-term lending ties to borrowers perform an important monitoring role in discouraging client firms' aggressive earnings management. Thus, long-term banking relations mitigate banks' perverse incentives as short-term creditors, particularly when the economy is performing well. Overall, the results in Panel B of Table $\mathrm{V}$ indicate that disincentives faced by main banks to monitor borrower accrual management in the offering year are stronger when the whole banking sector experiences difficulty and the main banks are exposed to more short-term lending. These disincentives are particularly strong when weak main banks maintain short-term lending relationships with poorly performing. In contrast, such disincentives do not exit during a boom period.

\section{Earnings management and post-offering lending by main banks}

To further examine whether the degree of earnings management around equity offerings during the banking crisis is related to bank relationships, we investigate the relation between the change in a firm's loans from the main bank immediately after an equity offering and the adjusted discretionary current accruals in the offering year. If the positive association between lending relationships and abnormal accruals during a banking crisis documented in Table $\mathrm{V}$ is indeed due to bank incentives to act primarily in the interests of short-term creditors, the banks are more likely to require the issuers that report higher income-increasing abnormal accruals to use the offering proceeds to repay the short-term loans. Therefore, as stated in $H 3$, our argument on banks' incentives to preserve their claims on borrowers during a crisis predicts that the main bank is more likely to decrease loans after the offerings as its client firms engage in more aggressive earnings management.

Table VI reports the results of this test. The dependent variable is a dummy that has a value of one if 
loans (total loans, short-term loans, or long-term loans) to the firm increase from year -1 to year +1 , and zero otherwise. The first three regressions use the full sample. The results show that the coefficient on adjusted discretionary current accruals in the offering year is negative and significant only in the regressions in which a dummy for an increase in short-term loans is used as the dependent variable.

In the next three regressions, we use a subsample of issuers that have main banks. We find that the more aggressively the firm engages in earnings management, the more likely the main bank curtails its short-term loans to the firm. Recall that the short-term main bank loan ratio prior to the offerings is positively related to the level of discretionary accruals in Table V. Here we find that the firms with large discretionary accruals experience a reduction in short-term main bank loans after the offerings. Taken together, these results suggest that the firms that engage in aggressive income-increasing earnings management are the firms that face reduced main bank lending subsequent to the offerings.

To examine whether incentives faced by banks to reduce loans to the firm vary depending on the financial health of the banking sector, we again separate the full sample into two subperiods, the pre-crisis period and the crisis period, and re-estimate the regressions separately for each period. The results are reported in regressions (7), (8), and (9) (before the crisis) and regressions (10), (11), and (12) (during the crisis). The significantly negative coefficient on adjusted discretionary current accruals is evident only in regression (11), which uses a dummy for an increase in short-term main bank loans during the banking crisis as the dependent variable. Overall, these results are consistent with $H 3$.

Using data from 1993 to 1999, Peek and Rosengren (2005) examine the misallocation of bank credit in Japan and find that firms are more likely to receive additional bank loans if they are in poor financial condition. They argue that bank incentives to "evergreen" loans arise for several reasons, including banks' self-interest to avoid a further increase in its reported nonperforming loans or government pressure on banks to continue to lend to financially impaired firms in order to boost the employment rate. However, unlike our sample firms, which were able to issue equity at the market price during the crisis period, the sample firms that drive the key results in Peek and Rosengren (2005) are those that were not 
economically viable and thus the loans to these firms were not likely to be profitable to the bank. For example, the average operating income to total assets for our sample firms during the banking crisis is $10.22 \%$ (the median industry-adjusted operating income to total assets is $5.08 \%$, which is significant at the 0.01 level). In comparison, the corresponding number in Peek and Rosengren (2005) is only $2.97 \%{ }^{16}$ This suggests that our sample firms are in better financial condition than those used in Peek and Rosengren (2005). Thus, it is not surprising to see the difference in bank lending behavior between the two studies. In particular, while Peek and Rosengren (2005) show that Japanese banks that were under great pressure to meet capital adequacy requirements during the crisis continued lending to poorly performing firms, ${ }^{17}$ our results indicate that these banks reduce credit to financially stronger firms that can raise capital on their own, possibly so that they can provide required credit to poorly performing firms. Our results therefore show that the misallocation of credit in Japan during the banking crisis exists not only for poorly performing firms, but also for relatively good performing firms.

\section{Sensitivity and additional tests}

\section{A. Do discretionary accruals measure earnings management?}

While the significant income-increasing discretionary accruals in the offering year that we document in the previous section suggest the presence of earnings management, they are also consistent with the view that managers time equity offerings to follow periods of unexpectedly high accruals (Shivakumar (2000)). To determine the extent to which these accruals are the result of managers' attempts to manage earnings, we regress post-offering changes in net income on adjusted discretionary current accruals in year 0 and adjusted discretionary current accruals in year -1 . The change in net income is computed by subtracting net income in year 0 from each of the subsequent years' net income.

\footnotetext{
${ }^{16}$ The $25^{\text {th }}$ quartile of operating income to total assets for our sample is $5.0 \%$ (the $25^{\text {th }}$ quartile of the median industry-adjusted operating income to total assets is $2.15 \%$ ). Thus, even our sample firms with the worst performance on average perform better than the sample firms used in Peek and Rosengren (2005).

${ }^{17}$ Consistent with this result, Kang and Liu (2008) find that the bank loan announcement returns for borrowing firms in Japan are negatively related to those for lending banks, especially when poorly performing firms borrow from financially healthy banks.
} 
The untabulated results show that the coefficient on the adjusted discretionary current accruals in year 0 is -0.017 with a $t$-statistic of -2.52 when changes in net income from year 0 to year +1 are used as the dependent variable. However, the coefficient on the adjusted discretionary current accruals in year -1 is not significant, suggesting that earnings management takes place mainly in year 0 . When we use the change in net income from year 0 to year +2 , the coefficient on the adjusted discretionary current accruals in year 0 is again negative with a $t$-statistic of 2.37 and the coefficient on the adjusted discretionary current accruals in year -1 is not significant. The negative and significant relation between discretionary accruals in the offering year and post-offering changes in net income is consistent with the findings of Teoh, Welch, and Wong (1998) and Rangan (1998), and suggests that the abnormally high accruals in year 0 that we document in the previous section are likely to be the result of intentional earnings management.

\section{B. Link between earnings management and announcement returns of equity offerings}

The main hypotheses we have examined so far rest on the premise that investors are fooled by earnings management and misprice the stock when seasoned equity is issued (Teoh, Welch, and Wang, (1998), Rangan (1998)). However, in contrast to this assumption, Shivakumar (2000) shows that investors in the U.S. rationally infer earnings management from offering announcements and offset the effects of the earnings management at offering announcements. Shivakumar (2000) argues that earnings management around the offerings is not intended to mislead investors, but reflects the rational response of issuers to anticipated market behavior at issue announcements. In this section, we examine whether investors in Japan also see through issuers' attempts to engage in earnings management and undo the price impact of earnings management.

To address this issue, we first estimate abnormal returns around the announcement of equity offerings. Table VII presents the cumulative abnormal returns (CARs). We obtain announcement dates of equity offerings from daily issues of the Nihon Keizai Shinbun, which is Japan's equivalent of the Wall 
Street Journal. We calculate the abnormal returns using two different approaches. First, for each issue announcement, we calculate the daily abnormal returns using a standard event study methodology. We obtain market model estimates by using 200 trading days of returns data, beginning 220 days before and ending 21 days before the issue announcement. Our benchmark market return is the PACAP equally weighted market return. We cumulate daily abnormal returns to obtain a CAR from day $-t$ before the issue announcement to day $+t$ after the issue announcement. Second, we follow Shivakumar (2000) and compute abnormal returns as the difference in returns between the sample firm and a growth-matched firm that is chosen based on the growth rate of sales.

We find that the mean CAR $(-1,0)$ and mean CAR $(-1,+1)$ using the market model are, respectively, $0.62 \%$ and $0.79 \%$, both of which are significant at the 0.05 level. The results using growth-firm adjusted returns are similar. The positive and statistically significant CARs for Japanese firms that issue equity contrast sharply with much of the evidence on issuing firms from the U.S., which documents a statistically significant negative average stock market reaction around equity issuance announcements (Asquith and Mullins (1986), Smith (1986)). These results are consistent, however, with those of Kang and Stulz (1996) and Cooney, Kato, and Schallheim (2003), who show that the stock price reaction to public placements of equity in Japan is significantly positive from 1985 to 1991 and from 1974 to 1993 , respectively.

To examine whether investors correct the price impact of earlier earnings management, we regress CAR $(-1,1)$ estimated using a growth-matched firm approach on the abnormal accruals in the offering year. To render our results comparable to those of Shivakumar (2000), in addition to variables used in Table V, the regressions include the individual stock returns during the previous one year before the offer announcement and the market returns during the same period. The regression results using the full sample are reported in Table VIII. The coefficients on the abnormal accruals in regressions (1) through (4) are not significant. These results are in contrast to those of Shivakumar (2000) and suggest that unlike in the U.S., Japanese investors are not able to detect issuers' attempts to engage in earnings management. 
In untabulated tests, we also find that the coefficients on the abnormal accruals are not significant in either boom or crisis period. Thus, although it is argued that Japanese financial markets become more liberalized and efficient during the later part of our sample period, our results suggest that corporate earnings management continue to mislead the public.

\section{Alternative explanations}

\section{C.1. Diversification motive of financing sources}

A concern in the interpretation of our results is that firms may engage in earnings management not because their main bank seeks to extract larger proceeds from the offerings, but because managers want to reduce the loans from their main bank and diversify financing sources. This alternative explanation is consistent with findings in Table $\mathrm{V}$, which shows a positive relation between abnormal accruals and the short-term main bank loan ratio in year -1, and in Table VI, which shows a negative relation between the likelihood of an increase in short-term main bank loans from year -1 to year +1 and the short-term main bank loan ratio in year -1 . In untabulated tests, we investigate this alternative explanation as follows.

First, we divide our sample firms into two groups, firms with poor past operating performance and firms with good past operating performance, and examine whether abnormal accruals and changes in short-term main banks' loans are different between these two groups. To the extent that the good performance group is more likely to easily access other means of financing offered by capital markets than the poor performance group, the alternative explanation suggests that compared to the poor performance group, the good performance group engages in more aggressive earnings management prior to the offerings and borrows less from the main bank after the offerings. We find that when we use the ratio of operating income to total assets in year -1 as a measure of firm performance, the mean (median) adjusted discretionary current accrual in year 0 for the good performance group is $2.2 \%(2.2 \%)$ and that for the poor performance group is $2.4 \%(2.2 \%)$. The mean (median) changes in the short-term main bank loan ratio from year -1 to year +1 and from year -1 to year +2 for the good performance group are, 
respectively, $0.31 \%(0 \%)$ and $0.67 \%(0 \%)$ and those for the poor performance group are $-0.07 \%(-0.03 \%)$ and $0.79 \%(0 \%)$. Tests of differences in mean and median abnormal accruals and of differences in mean and median changes in the short-term main bank loan ratios across the two subsamples do not reject the null hypothesis that they are equal. Similar results obtain when we use past excess stock returns and the standard deviation of the ratio of operating income to total assets over the past 10 years as measures of firm performance. These results are not consistent with the prediction of a diversification story.

Second, it can be argued that large firms generally find it easier to secure external financing and are less likely to rely mostly on bank borrowing for their financing than smaller firms. Therefore, the alternative explanation based on the diversification motive predicts that compared to small firms, large firms engage in more aggressive earnings management prior to offerings and borrow less from their main bank after offerings. However, the results show that there are no discernible differences in abnormal accruals and changes in short-term main bank loan ratios between small and large firms.

Third, the diversification story suggests that firms that engage in aggressive earnings management prior to the offerings are more likely to be in the capital markets to secure funds with which to diversify their financing sources. This argument implies that compared to firms with a single issuance of public equity (securities), those with multiple issuances of public equity (securities) during our sample period are likely to manage earnings more aggressively and borrow less from their main bank after the offerings. However, the results show no differences in abnormal accruals and changes in short-term main bank loan ratios between firms that make only one issuance of public equity and those that make multiple issuances of public equity, or between firms that make only one issuance of public equity and those that make multiple issuances of public securities such as equity, straight debt, and convertible bonds. Overall, these results are not consistent with the alternative explanation based on the diversification motive of financing sources. $^{18}$

\footnotetext{
${ }^{18}$ In untabulated tests, we examine whether the probability of raising capital from the financial markets depends on the financial health of the main bank. Using a logit regression analysis in which the probability we model is the likelihood of issuing either equity, straight bonds, or convertible bonds, we find that during a sample period of 1983
} 


\section{C.2. Regulatory rules concerning public equity offerings in the 1980s}

Until 1996, public equity offerings in the Japanese stock market were heavily regulated (Hoshi and Kashyap (2001)), with firms required to satisfy the issuance criteria set by each of the major securities companies before being allowed to issue new shares. The criteria extended to profits, requiring that (1) the firm have ordinary profits (after taxes) that are equal to or greater than 10 yen per share in the previous year, and (2) the firm's ordinary profits (after taxes) after a new stock issue be expected to increase (Hirota, 1999). ${ }^{19}$ In April 1996 these regulations were abolished. Given these rules, one may expect the results in this paper to be driven in part by regulatory effects for the period before April 1996. For example, the previous section shows that poorly performing firms are more likely to engage in income-increasing earnings management than good performing firms. To the extent that poorly performing firms have to manage earnings more aggressively in order to satisfy the issuing criteria, this result is consistent with the view that regulatory rules concerning public equity offerings in the $1980 \mathrm{~s}$ increase firms' incentives to manage earnings in the way that our paper suggests. Although we use performance-adjusted accruals to mitigate this concern and we control for the past operating performance of an issuer in the regression analysis, it is still possible that regulatory effects drive some of our main results.

To further investigate the effect of regulatory rules on earnings management, we split our sample of 431 issuing firms from 1983 to March 1996 according to the two issuing criteria listed above: (1) whether the firm's ordinary profits (after taxes) are equal to or greater than 10 yen per share in the previous year, and (2) whether the firm's post-offering ordinary profits (after taxes) increase. The results are reported in Table IX. We find that abnormal accruals are positive and significant for all subsamples and their

to 2003 , firms with a poorly performing main bank in the PACAP database are less likely to raise capital elsewhere than firms with a good performing main bank. This result suggests that firms with a financially weak main bank have difficulties obtaining external financing and thus are more likely to be influenced by their main bank. We also find that firms with higher Tobin's q are more likely to issue securities.

${ }^{19}$ These rules were introduced in February 1973. 
differences in mean and median abnormal accruals are not significant. Thus, although regulatory equity issuance requirements on firm performance may have an effect on incentives to manage earnings upward, our results are not consistent with such explanation.

\section{C.3. Endogeneity bias}

In interpreting our regression results, the degree to which the main bank relationship is endogenously determined must be taken into account. It is possible that certain types of firms choose to have a certain type of main bank relationship. For example, if poorly performing firms borrow extensively from banks, and if earnings management simply reflects this poor performance, we might detect a spurious relation between bank financing and earnings management. To address this endogeneity issue, we re-estimate the regressions in Table $\mathrm{V}$ using the two-year lagged values of bank loans as instrumental variables. In untabulated tests, we find that the results from the instrumental variables regression are similar to those reported in Table V. We also use the three-year lagged values instead of the two-year lagged values and find that the results are similar.

Another endogeneity issue is whether our findings reflect a causal link between bank ties and earnings management. Perhaps clients of poorly performing banks are themselves poorly performing firms, in which case the results have nothing to do with disincentives faced by banks to monitor. Using lagged bank ties as an instrument is not an appropriate solution to this problem since main bank ties may be stable over time by definition. We address this issue by dividing our sample into good and poorly performing firms according to the median ratio of cash flows to total assets and then examining whether the financial health of affiliated main banks of each group is different across these two subsamples. Untabulated tests show that the financial health of main banks, measured by the ratio of operating income to total assets, market-adjusted cumulative excess returns, or the standard deviation of the ratio of operating income to total assets over the past 10 years, is statistically indistinguishable between good and poorly performing firms. While the financial health of main banks measured by Tobin's q is significantly 
different between these two types of firms, the results are opposite in that poorly performing firms are associated with main banks with a higher Tobin's q. Thus, it is unlikely that our results are driven by the fact that financially weak banks are mainly associated with poorly performing clients.

\section{C.4. Alternative measures of bank relationships}

To check the robustness of the results on the link between bank ties and earnings management, we reestimate the regressions in Table $\mathrm{V}$ using an alternative measure of bank relationships. If the bank's disincentive to monitor the issuer's income-increasing earnings management is largely due to preserving its debt claims on borrowers, then the size of the main bank's outstanding claim (i.e., the face value of the main bank's loans to the firm) may be arguably a more appropriate measure of the main bank's exposure to the firm than the main bank's share of the firm's debt. To test this view, we re-estimate the regressions in Table $\mathrm{V}$ by replacing the bank loan ratios with the face value of the bank loans. The results are qualitatively similar. We find that the coefficient on the log of short-term loans from the main bank is negative and significant for the full period and the 1993-2002 subperiod. The coefficient on the $\log$ of long-term loans from the main bank, however, is not significant.

\section{C.5. Past performance of borrowers}

Our main results so far are that during a banking crisis, firms engage in more aggressive earnings management when their main bank has a large debt claim and that the main bank's debt claim declines following the issue. We argue that it is the bank's incentive to preserve its claims on borrowers and the lack of its monitoring resources, that cause these results. However, these results are also consistent with the following alternative story: Firms with low cash flows increase their borrowings from their main bank, consistent with main banks having a responsibility to firms in financial trouble. Such firms are also likely to manage earnings and to sell equity to receive a cash infusion. Following the cash infusion, the firm pays down some of its temporarily large claim to its main bank. According to this story, there is no 
causality running from the main bank's disincentives to the firm's behavior, but this story is also consistent with the results we document above. To examine whether this alternative story can also explain our results, in untabulated tests we again divide our sample into firms with high cash flows (cash flow / total assets) and those with low cash flows according to the sample median in year $\mathrm{t}-1$ and then compare the change in loans before the offering from $t-2$ to $t-1$ and the change in loans after the offering from $t-1$ to $t+1$. We find that for low cash flow firms, the mean and median changes in short-term main bank loans from year $\mathrm{t}-2$ to year $\mathrm{t}-1$ are -0.0012 and 0.000 , respectively. For high cash flow firms, the corresponding numbers are 0.0093 and 0.000 , respectively. Tests of differences in mean and median changes in short-term main bank loans across the two subgroups strongly reject the null hypothesis that they are equal ( $t$-value $=3.00, z$-value $=3.07)$. Thus, prior to equity issuance, main banks tend to collect more short-term loans from poorly performing firms than from good performing firms. We also find that from year $\mathrm{t}-1$ to year $\mathrm{t}+1$, the mean and median changes in short-term main bank loans for low cash flow firms are statistically indistinguishable from those for high cash flow firms. Taken together these results are not consistent with the predictions of the alternative story based on past performance of borrowers.

\section{C.6. Banks as underwriters}

Japan's Securities and Exchange Act of 1948 prohibited banks from underwriting securities until 1992. However, echoing the 1990s relaxation of the 1933 Glass-Steagall Act, which permits U.S. commercial banks to underwrite corporate securities, beginning April 1, 1993, the Financial System Reform Act (FSRA) in Japan removes restrictions that separated commercial and investment banking and allows Japanese commercial banks to provide investment banking services. Under the FSRA, Japanese commercial banks were allowed to establish subsidiary securities firms, and beginning October 1999, these subsidiary securities firms started to underwrite equity. Since unlike debtholders, underwriters have incentives to sell new shares at lower prices to make it easy to find potential buyers for equity offerings (Loughran and Ritter (2002)), banks are likely to have conflicting incentives in influencing firms to 
engage in earnings management when they serve as the underwriter as well as the lender. ${ }^{20}$ To examine whether the extent of earnings management by equity-issuing firms when the main banks serve as both their underwriters and their lenders is different from that when the main banks are only lenders, we separate our sample into issues in which the main banks serve as both underwriters and lenders and issues in which the main banks serve only as lenders. Out of 508 observations in our sample, $26(5.1 \%)$ equity issues are underwritten by the security firms that are subsidiaries of the main bank of the issuing firm. The mean (median) earnings management for this group is $0.017(-0.015)$. On the other hand, the mean (median) earnings management for the remaining 482 observations in which underwriters are not subsidiaries of the main bank of the issuing firm is $0.023(0.022)$. Thus, the level of earnings management is lower when banks serve as both the underwriter and the lender than when banks serve only as the lender. However, the difference in mean (median) earnings management across the two groups is not statistically significant.

\section{Summary and conclusions}

Using a sample of 508 issues of Japanese seasoned equity offerings from 1983 to 2002, this paper examines whether bank incentives to monitor borrower opportunistic behavior are affected by the health of the banking sector and the bank's financial condition. We find that firms with short-term ties to a main bank, as measured by the ratio of a firm's short-term borrowings from its main bank to total debt, engage more aggressively in earnings management around public equity offerings. This result, however, is observed only during 1993-2002, a period during which the Japanese economy experienced a significant deterioration in the financial health of the banking sector, and is most pronounced for poorly performing firms that maintain lending ties to a financially weak main bank. These results suggest that during a

${ }^{20}$ For a discussion of two competing views (certification and conflict of interest) regarding the role of commercial banks in underwriting the securities of firms with which they maintain lending relationships, see Kroszner and Rajan (1994), Puri (1996), and Gande, Puri, Saunders, and Walter (1997). Unlike these studies that examine bond pricing in the U.S. and find results that are consistent with the certification view, Hamao and Hoshi (2004) and Kang and Liu (2007) examine bond pricing in the post-FSRA period in Japan and find results that are broadly consistent with the conflict of interest view. Using a sample of Israeli IPOs, Ber, Yafeh, and Yosha (2001) also present evidence of conflicts of interest in combining bank lending, underwriting, and fund management. 
banking crisis, the bank's incentives to preserve its claims on borrowers and the lack of its monitoring resources provide weak banks disincentives to monitor the opportunistic financial reporting behavior of equity-issuing borrowers prior to an offering.

We also find that the post-offering short-term lending relationship between main banks and issuers becomes significantly weaker for issuers that manage earnings aggressively in the offering year. Our result suggests that when the entire banking sector suffers from the credit crunch, banks have strong incentives to reduce credit to firms that are relatively weak but can raise capital on their own. These results, together with those of Peek and Rosengren (2005), suggest that during a banking crisis, Japanese banks allocate more credit to troubled borrowers and less credit to borrowers that are still economically viable.

Although our tests identify earnings management around a borrower's equity financing during a banking crisis as the mechanism through which banks preserve their claims on borrowers, these incentives faced by banks could also arise in other instances. The questions of when the costs of strong bank ties outweigh the benefits, of when banks exercise strong control over client firms, and of when banks facilitate decisions that enhance versus harm client firm value represent useful areas for additional work. 


\section{References}

Admati, Anat R., and Paul Pfleiderer, 1994, Robust financial contracting and the role of venture capitalists, Journal of Finance 49, 371-402.

Ahn, Sungyoon, and Wooseok Choi, 2009, The role of bank monitoring in corporate governance: Evidence from borrowers' earnings management behavior, Journal of Banking and Finance 33, 425434.

Anthony, Joseph H., Bruce Bettinghaus, and David B. Farber, 2005, The magnitude, frequency, and limiting factors of earnings management for capital market purposes: Evidence from the issuance of public securities, Working paper, Michigan State University.

Aoki, Masahiko, 1990, Toward an economic model of the Japanese firm, Journal of Economic Literature 28, 1-27.

Aoki, Masahiko, Hugh Patrick, and Paul Sheard, 1994, The Japanese main bank system: An introductory overview, in Masahiko Aoki and Hugh Patrick, ed.: The Japanese Main Bank System: Its Relevancy for Developing and Transforming Socialist Economies, Cary, NC: Oxford University Press.

Asquith, Paul, and David W. Mullins, Jr. 1986, Equity issues and offering dilution, Journal of Financial Economics 15, 61-89.

Ber, Hedva, Yishay Yafeh, and Oved Yosha, 2001, Conflict of interest in universal banking: bank lending, stock underwriting, and fund management. Journal of Monetary Economics 47, 189-218.

Brewer, Elijah, III, Hesna Genay, William Curt Hunter, and George G. Kaufman, 2003, The value of banking relationships during a financial crisis: Evidence from failures of Japanese banks, Journal of the Japanese and International Economies 17, 233-262.

Choi, Wooseok, 2005, Firm-bank relationships and the corporate governance role of banks: Evidence from borrowers' accounting conservatism, Working paper, California State University, Los Angeles.

Cooney, John W., Hideaki Kiyoshi Kato, and James S. Schallheim, 2003, Underwriter certification and Japanese seasoned equity issues, Review of Financial Studies 16, 949-982.

Darrough, Masako, and Srinivasan Rangan, 2005, 2005, Do managers manipulate R\&D spending when they sell their shares in an initial public offering? Journal of Accounting Research 43, 1-33.

Dechow, Patricia M., Richard G. Sloan, and Amy P. Sweeney, 1995, Detecting earnings management, The Accounting Review 70, 193-225.

Dechow, Patricia M., S.A. Richardson, and I. Tuna, 2003, Why are earnings kinky? An examination of the earnings management explanation, Review of Accounting Studies 8: 355-384.

Diamond, Douglas W., 1984, Financial intermediation and delegated monitoring, Review of Economic Studies 51, 393-414.

Diamond, Douglas W., 1991, Monitoring and reputation: The choice between banks and directly placed debt, Journal of Political Economy 99, 689-721. 
DuCharme, Larry, Paul Malatesta, and Stephan Sefcik, 2004, Earnings management, stock issues, and shareholder lawsuits, Journal of Financial Economics 71, 27-40.

Erickson, Merle, and Shiing-Wu Wang, 1999, Earnings management by acquiring firms in stock for stock mergers, Journal of Accounting and Economics 27, 149-176.

Fama, Eugene, 1985, What's different about banks? Journal of Monetary Economics 10, 10-19.

Fukao, Mitsuhiro, 2003, Financial sector profitability and double-gearing, in Magnus Blomstrom, Jennifer Corbett, Fumio Hayashi, and Anil Kashyap, ed. Structural Impediments to Growth in Japan, Chicago, IL: University of Chicago Press.

Gande, Amar, Manju Puri, Anthony Saunders, and Ingo Walter, 1997, Bank underwriting of debt securities: Modern evidence, Review of Financial Studies 10, 1175-1202.

Gaver, Jennifer J., Kenneth M. Gaver, and Jeffrey R. Austin, 1995, Additional evidence on bonus plans and income management, Journal of Accounting and Economics 19, 3-28.

Gibson, Michael S., 1995, Can bank health affect investment? Evidence from Japan, Journal of Business 68, 281-308.

Gong, Guojin, Henock Louis, and Amy X.. Sun, 2008, Earnings management and firm performance following open-market repurchases, Journal of Finance 63, 947-966.

Hamao, Yasushi, and Takeo Hoshi, 2004. Bank underwriting of corporate bonds: evidence from Japan after the financial system reform of 1993, Working Paper. University of California, San Diego.

Healy, Paul M., James Wahlen, 1999, A review of the earnings management literature and its implications for standard setting, Accounting Horizon 13, 365-384.

Hickock, S. and C. Osler, 1994, The credit slowdown abroad, in Studies on Causes and Consequences of the 1989-1992 Credit Slowdown, Federal Reserve Bank of New York, New York.

Hirota, Shin'ichi, 1999, Are corporate financing decisions different in Japan? An empirical study on capital structure, Journal of the Japanese and International Economics 13, 201-229.

Holmstrom, Bengt, and Jean Tirole, 1997, Financial intermediation, loanable funds, and the real sector, Quarterly Journal of Economics 112, 663-691.

Hoshi, Takeo, and Anil Kashyap, 2001, Corporate financing and governance in Japan: The road to the future, Cambridge, MA: The MIT Press.

Hoshi, Takeo, Anil Kashyap, and David Scharfstein, 1990, The role of banks in reducing the costs of financial distress in Japan, Journal of Financial Economics 27, 67-88.

Hoshi, Takeo, Anil Kashyap, and David Scharfstein, 1991, Corporate structure, liquidity and investment: evidence from Japanese industrial groups, Quarterly Journal of Economics 106, 33-60.

Jensen, Michael C., 1989, Eclipse of the public corporation, Harvard Business Review 5, 61-74. 
Jones, Jennifer J., 1991, Earnings management during import relief investigation, Journal of Accounting Research 29, 193-228.

Kang, Jun-Koo, and Wei-Lin Liu, 2008, Bank incentives and suboptimal lending decisions: Evidence from the valuation effect of bank loan announcements in Japan, Journal of Banking and Finance 32, 915-929.

Kang, Jun-Koo, and Wei-Lin Liu, 2008, Is universal banking justified? Evidence from bank underwriting of corporate bonds in Japan, Journal of Financial Economics 84, 142-186.

Kang, Jun-Koo, and Rene M. Stulz, 1996, How different is Japanese corporate finance? An investigation of the information content of new security issues, Review of Financial Studies 9, 109-139.

Kang, Jun-Koo, and Anil Shivdasani, 1995, Firm performance, corporate governance, and top executive turnover in Japan, Journal of Financial Economics 38, 29-58.

Kang, Jun-Koo, and Rene M. Stulz, 2000, Do banking shocks affect borrowing firm performance? An analysis of the Japanese experience, Journal of Business 73, 1-23.

Kaplan, Steven N., 1994, Top executive rewards and firm performance: A comparison of Japan and the United States, Journal of Political Economy 102, 510-546.

Kaplan, Steven N., and Bernadette A. Minton, 1994, Appointments of outsiders to Japanese boards: Determinants and implications for managers, Journal of Financial Economics 36, 225-258.

Kim, Yongtae, and Myung Seok Park, 2005, Pricing of seasoned equity offers and earnings management, Journal of Financial and Quantitative Analysis 40, 435-463.

Kothari, S. P., Andrew J. Leone, and Charles E. Wasley, 2004, Performance matched discretionary accrual measures, Journal of Accounting and Economics 39, 163-197.

Kroszner, Randall S., and Raghuram G. Rajan, 1994, Is the Glass-Steagall Act justified? A study of the U.S. experience with universal banking before 1933, American Economic Review 84, 810-832.

Kroszner, Randall S., and Philip E. Strahan, 2001, Bankers on boards: Monitoring, conflicts of interest, and lender liability, Journal of Financial Economics 62, 415-452.

Loughran, Tim, and Jay R. Ritter, 2002. Why don't issuers get upset about leaving money on the table in IPOS? Review of Financial Studies 15, 413-443.

Louis, Henock, 2004, Earnings management and the market performance of acquiring firms, Journal of Financial Economics 74, 121-148.

Miyajima, Hideaki, and Yishay Yafeh, 2007, Japan's banking crisis: An event study perspective, Journal of Banking and Finance 31, 2866-2885.

Morck, Randall, and Masao Nakamura, 1999, Banks and corporate control in Japan, Journal of Finance 54, 319-339. 
Peek, Joe, and Eric S. Rosengren, 2005, Unnatural selection: Perverse incentives and the misallocation of credit in Japan, American Economic Review 95, 1144-1166.

Puri, Manju, 1996, Commercial banks in investment banking: Conflict of interest or certification role? Journal of Financial Economics 40, 373-401.

Rajan, Raghuram, 1992, Insiders and outsiders: The choice between relationship and arm's length debt, Journal of Finance 47, 1367-1400.

Ramakrishnan, Ram, and Anjan Thakor, 1984. Information reliability and a theory of financial intermediation. Review of Economic Studies 52, 415-432.

Rangan, Srinivasan, 1998, Earnings management and the performance of seasoned equity issues, Journal of Financial Economics 50, 101-122.

Sharpe, Steven, 1990, Asymmetric information, bank lending, and implicit contracts: A stylized model of customer relationship, Journal of Finance 45, 1069-1087.

Sheard, Paul, 1989, The main bank system and corporate monitoring and control in Japan, Journal of Economic Behavior and Organization 11, 399-422.

Sheard, Paul, 1994, Main banks and the governance of financial distress, in The Japanese main bank system: An introductory overview, in Masahiko Aoki and Hugh Patrick, ed.: The Japanese Main Bank System: Its Relevancy for Developing and Transforming Socialist Economies, Cary, NC: Oxford University Press.

Shivakumar, Lakshmanan, 2000, Do firms mislead investors by overstating earnings before seasoned equity offerings? Journal of Accounting Economics 29, 339-371.

Sloan, Richard, 1996, Do stock prices fully reflect information in accruals and cash flows about future earnings?, The Accounting Review 77, 289-315.

Slovin, Myron B., Marie F. Sushka, and John A. Polonchek, 1993, The value of bank durability: borrowers and bank stakeholders, Journal of Finance 48, 247-266.

Smith, Clifford W., 1986, Investment banking and the capital acquisition process, Journal of Financial Economics 15, 3-29.

Teoh, Siew Hong, Ivo Welch, and T.J. Wong, 1998, Earnings management and the underperformance of seasoned equity offerings, Journal of Financial Economics 50, 63-99.

Weinstein, David E., and Yishay Yafeh, 1998, On the costs of a bank-centered financial system: Evidence from changing main bank relationships in Japan, Journal of Finance 53, 635-672. 
Table I

Distribution of public equity offerings by year and industry

The sample consists of 508 issues of Japanese seasoned equity offerings from 1983 to 2002. The sample comes from the Tokyo Stock Exchange Annual Securities Statistics, supplemented by Thomson Financial Securities data and NEEDS corporate finance-related data. Firms belonging to either financial services or utilities industries and those that issued multiple classes of securities within three years prior to or subsequent to the offering are excluded from the sample.

\begin{tabular}{|c|c|c|c|c|c|c|c|}
\hline- & Construction & Manufacturing & $\begin{array}{c}\text { Wholesale \& } \\
\text { retail trade }\end{array}$ & Real estate & $\begin{array}{l}\text { Transportation \& } \\
\text { communication }\end{array}$ & Services & Total \\
\hline 1983 & 3 & 35 & 11 & 1 & 1 & 2 & 53 \\
\hline 1984 & 2 & 45 & 10 & 2 & 1 & 4 & 64 \\
\hline 1985 & 0 & 24 & 7 & 0 & 2 & 0 & 33 \\
\hline 1986 & 3 & 19 & 6 & 0 & 1 & 1 & 30 \\
\hline 1987 & 2 & 11 & 8 & 1 & 1 & 2 & 25 \\
\hline 1988 & 6 & 31 & 10 & 1 & 3 & 3 & 54 \\
\hline 1989 & 7 & 63 & 18 & 2 & 5 & 2 & 97 \\
\hline 1990 & 2 & 22 & 4 & 1 & 5 & 3 & 37 \\
\hline 1991 & 0 & 12 & 2 & 0 & 0 & 2 & 16 \\
\hline 1992 & 1 & 4 & 1 & 0 & 0 & 0 & 6 \\
\hline 1993 & 0 & 0 & 0 & 0 & 1 & 0 & 1 \\
\hline 1994 & 4 & 2 & 4 & 0 & 1 & 0 & 11 \\
\hline 1995 & 0 & 3 & 1 & 0 & 0 & 0 & 4 \\
\hline 1996 & 2 & 12 & 2 & 0 & 0 & 0 & 16 \\
\hline 1997 & 1 & 1 & 3 & 0 & 0 & 1 & 6 \\
\hline 1998 & 0 & 2 & 2 & 0 & 0 & 1 & 5 \\
\hline 1999 & 0 & 5 & 9 & 1 & 0 & 7 & 22 \\
\hline 2000 & 0 & 5 & 3 & 0 & 2 & 3 & 13 \\
\hline 2001 & 0 & 4 & 2 & 1 & 0 & 1 & 8 \\
\hline 2002 & 1 & 4 & 2 & 0 & 0 & 0 & 7 \\
\hline Total & 34 & 306 & 103 & 10 & 23 & 32 & 508 \\
\hline
\end{tabular}


Table II

Sample characteristics

The sample consists of 508 issues of Japanese seasoned equity offerings from 1983 to 2002. The sample comes from the Tokyo Stock Exchange Annual Securities Statistics, supplemented by Thomson Financial Securities data and NEEDS corporate finance-related data. Firms belonging to either financial services or utilities industries and those that issued multiple classes of securities within three years prior to or subsequent to the offering are excluded from the sample. Tobin's q is the ratio of the sum of the book value of debt and the market value of equity to total assets. Firms are considered to be members of a keiretsu if they belong to any of the six bank-centered keiretsu (Mitsubishi, Mitsui, Sumitomo, Fuyo, DKB, and Sanwa). The main bank is a firm's largest lender. The standard deviation of operating income is the standard deviation of the ratio of operating income to total assets over the past ten years.

\begin{tabular}{|c|c|c|c|c|c|}
\hline & Mean & Median & $1 \mathrm{Q}$ & $3 \mathrm{Q}$ & $\begin{array}{l}\text { Standard } \\
\text { deviation }\end{array}$ \\
\hline \multicolumn{6}{|l|}{ Issuer/Issue characteristics } \\
\hline Market value of equity (in billion yen) & 130.527 & 37.074 & 17.216 & 88.712 & 388.070 \\
\hline Total assets (in billion yen) & 136.675 & 34.770 & 19.403 & 61.129 & 449.650 \\
\hline Issue amount (in billion yen) & 9.395 & 3.749 & 1.862 & 8.324 & 19.630 \\
\hline Issue amount / market value of equity & 0.086 & 0.088 & 0.054 & 0.117 & 0.048 \\
\hline Operating income / total assets & 0.069 & 0.062 & 0.038 & 0.087 & 0.047 \\
\hline $\begin{array}{l}\text { Market-adjusted excess returns over } \\
\text { the past } 1 \text { year }\end{array}$ & 0.145 & 0.063 & -0.107 & 0.319 & 0.417 \\
\hline Leverage (debt / total assets) & 0.654 & 0.680 & 0.518 & 0.815 & 0.195 \\
\hline Tobin's q & 2.059 & 1.750 & 1.364 & 2.300 & 1.188 \\
\hline Bank loans / total debt & 0.254 & 0.246 & 0.104 & 0.366 & 0.187 \\
\hline Short-term bank loans / total debt & 0.157 & 0.140 & 0.049 & 0.235 & 0.133 \\
\hline Long-term bank loans / total debt & 0.096 & 0.058 & 0.001 & 0.145 & 0.120 \\
\hline Main bank loans / total debt & 0.089 & 0.071 & 0.040 & 0.115 & 0.069 \\
\hline Short-term main bank loans / total debt & 0.053 & 0.040 & 0.018 & 0.072 & 0.052 \\
\hline Long-term main bank loans / total debt & 0.036 & 0.017 & 0.0003 & 0.050 & 0.051 \\
\hline Other bank loans / total debt & 0.177 & 0.147 & 0.068 & 0.244 & 0.181 \\
\hline Short-term other bank loans / total debt & 0.112 & 0.093 & 0.032 & 0.161 & 0.119 \\
\hline Long-term other bank loans / total debt & 0.066 & 0.032 & 0.0003 & 0.092 & 0.111 \\
\hline Equity ownership by financial institutions & 0.275 & 0.259 & 0.162 & 0.376 & 0.143 \\
\hline Equity ownership by other corporations & 0.318 & 0.301 & 0.173 & 0.453 & 0.181 \\
\hline Equity ownership by foreigners & 0.052 & 0.027 & 0.005 & 0.077 & 0.060 \\
\hline Fraction of firms belonging to a keiretsu & 0.187 & 0 & 0 & 0 & 0.390 \\
\hline \multicolumn{6}{|l|}{ Main bank characteristics } \\
\hline Operating income / total assets & 0.004 & 0.005 & 0.004 & 0.006 & 0.005 \\
\hline $\begin{array}{l}\text { Market-adjusted excess returns over the } \\
\text { past } 1 \text { year }\end{array}$ & -0.0004 & -0.113 & -0.212 & 0.171 & 0.316 \\
\hline Tobin's q & 1.096 & 1.091 & 1.054 & 1.141 & 0.061 \\
\hline Standard deviation of operating income & 0.002 & 0.002 & 0.002 & 0.003 & 0.001 \\
\hline
\end{tabular}


Table III

Mean and median asset-scaled income from operation, cash flow from operations, and accruals around public equity offerings

The sample consists of 508 issues of Japanese seasoned equity offerings from 1983 to 2002 . The sample comes from the Tokyo Stock Exchange Annual Securities Statistics, supplemented by Thomson Financial Securities data and NEEDS corporate finance-related data. Firms belonging to either financial services or utilities industries and those that issued multiple classes of securities within three years prior to or subsequent to the offering are excluded from the sample. Cash flow from operations is measured as the ratio of net income minus accruals to the prior year's total assets. Current accruals are measured as the change in current assets other than cash and short-term investments in the two consecutive years ending in year $t$ less the change in current liabilities other than debt in the two consecutive years ending in year $t$. Adjusted discretionary current accruals are calculated by subtracting industry- and performance-matched non-issuers' discretionary current accruals from issuers' discretionary current accruals. Discretionary accruals are the differences between the actual accruals and the nondiscretionary accruals. Predicted (i.e., nondiscretionary) accruals are estimated using the cross-sectional adaptation of the modified Jones (1991) model. A non-issuer is matched to each issuer by industry (using the two-digit industry code) and the ROA for each year from year -3 to year +3 . ***, **, and * denote significance at the $0.01,0.5$, and 0.10 levels, respectively.

Panel A: Income from continuing operations / total assets (ROA)

\begin{tabular}{|c|c|c|c|c|c|c|c|}
\hline Year & -3 & -2 & -1 & 0 & 1 & 2 & 3 \\
\hline Mean & $0.066^{* * *}$ & $0.072^{* * *}$ & $0.082^{* * *}$ & $0.086^{* * *}$ & $0.070^{* * *}$ & $0.058^{* * *}$ & $0.050^{* * *}$ \\
\hline Median & $0.053^{* * *}$ & $0.058^{* * *}$ & $0.069^{* * *}$ & $0.071^{* * *}$ & $0.058^{* * *}$ & $0.050^{* * *}$ & $0.041^{* * *}$ \\
\hline \multicolumn{8}{|c|}{ Panel B: Cash flows from operations / total assets } \\
\hline Year & -3 & -2 & -1 & 0 & 1 & 2 & 3 \\
\hline Mean & $0.096^{* * *}$ & $0.098^{* * *}$ & $0.103^{* * *}$ & $0.083^{* * *}$ & $0.078^{* * *}$ & $0.075^{* * *}$ & $0.072^{* * *}$ \\
\hline Median & $0.086^{* * *}$ & $0.086^{* * *}$ & $0.104^{* * *}$ & $0.075^{* * *}$ & $0.079^{* * *}$ & $0.066^{* * *}$ & $0.068^{* * *}$ \\
\hline \multicolumn{8}{|c|}{ Panel C: Current accruals } \\
\hline Year & -3 & -2 & -1 & 0 & 1 & 2 & 3 \\
\hline Mean & -0.003 & -0.005 & 0.004 & $0.033^{* * *}$ & $0.019^{* * *}$ & $0.009^{* * *}$ & $0.007^{*}$ \\
\hline Median & -0.002 & 0.003 & 0.002 & $0.029^{* * *}$ & $0.011^{* * *}$ & $0.008^{* * *}$ & 0.003 \\
\hline \multicolumn{8}{|c|}{$\begin{array}{l}\text { Panel D: Adjusted discretionary current accruals (Issuers' discretionary current accruals minus industry-and } \\
\text { performance-matched non-issuers' discretionary current accruals) }\end{array}$} \\
\hline Year & -3 & -2 & -1 & 0 & 1 & 2 & 3 \\
\hline Mean & -0.007 & -0.007 & -0.004 & $0.023^{* * *}$ & $0.010^{* *}$ & 0.005 & 0.006 \\
\hline Median & -0.003 & 0.001 & -0.008 & $0.022^{* * *}$ & 0.004 & 0.001 & 0.001 \\
\hline
\end{tabular}


Table IV

Mean and median industry- and performance-adjusted discretionary current accruals in the offering year by subperiod and by industry

The sample consists of 508 issues of Japanese seasoned equity offerings from 1983 to 2002. The sample comes from the Tokyo Stock Exchange Annual Securities Statistics, supplemented by Thomson Financial Securities data and NEEDS corporate finance-related data. Firms belonging to either financial services or utilities industries and those that issued multiple classes of securities within three years prior to or subsequent to the offering are excluded from the sample. Industry- and performance-adjusted discretionary current accruals are calculated by subtracting industry- and performance-matched non-issuers' discretionary current accruals from issuers' discretionary current accruals. Discretionary accruals are the difference between the actual accruals and the nondiscretionary accruals. Predicted (i.e., nondiscretionary) accruals are estimated using the cross-sectional adaptation of the modified Jones (1991) model. A non-issuer is matched to each issuer by industry (using the two-digit industry code) and the ROA for each year. ${ }^{* * *}, * *$, and $*$ denote significance at the $0.01,0.5$, and 0.10 levels, respectively.

\begin{tabular}{|c|c|c|c|}
\hline & $\begin{array}{l}\text { Sample } \\
\text { size }\end{array}$ & Mean & Median \\
\hline $\begin{array}{l}\text { Boom period } \\
(1983-1989)\end{array}$ & 356 & $0.022^{* * *}$ & $0.022^{* * *}$ \\
\hline $\begin{array}{l}\text { Down period } \\
(1990-2002)\end{array}$ & 152 & $0.026^{* * *}$ & $0.019^{* *}$ \\
\hline$p$-value of difference & & 0.713 & 0.997 \\
\hline \multicolumn{4}{|c|}{ Panel B: Industry-and performance-adjusted discretionary current accruals in the offering year by industr. } \\
\hline & $\begin{array}{c}\text { Sample } \\
\text { size }\end{array}$ & Mean & Median \\
\hline Construction & 34 & 0.017 & 0.027 \\
\hline Manufacturing & 306 & $0.027^{* * *}$ & $0.026^{* * *}$ \\
\hline Wholesale and retail trade & 103 & $0.017^{*}$ & 0.013 \\
\hline Real estate & 10 & -0.034 & -0.053 \\
\hline $\begin{array}{l}\text { Transportation and } \\
\text { communication }\end{array}$ & 23 & -0.013 & -0.020 \\
\hline Services & 32 & $0.031^{*}$ & 0.035 \\
\hline Total & 508 & & \\
\hline
\end{tabular}


Table V

Multivariate regressions of industry- and performance-adjusted discretionary current accruals in the offering year on bank loan ratios

The sample consists of 508 issues of Japanese seasoned equity offerings from 1983 to 2002 . The sample comes from the Tokyo Stock Exchange Annual Securities Statistics, supplemented by Thomson Financial Securities data and NEEDS corporate finance-related data. Firms belonging to either financial services or utilities industries and those that issued multiple classes of securities within three years prior to or subsequent to the offering are excluded from the sample. The dependent variable is the adjusted discretionary current accruals in the year of the equity offerings. Adjusted discretionary current accruals are calculated by subtracting industry- and performance-matched non-issuers' discretionary current accruals from issuers' discretionary current accruals. Discretionary accruals are the difference between actual accruals and nondiscretionary accruals. Predicted (i.e., nondiscretionary) accruals are estimated using the cross-sectional adaptation of the modified Jones (1991) model. A non-issuer is matched to each issuer by industry (using the two-digit industry code) and the ROA for each year from year -3 to year +3 . Independent variables are measured at the fiscal year-end that comes immediately before the equity offerings. The main bank is a firm's largest lender. The keiretsu dummy takes the value of one if a firm belongs to any of the six bank-centered keiretsu (Mitsubishi, Mitsui, Sumitomo, Fuyo, DKB, and Sanwa). The standard deviation of operating income is the standard deviation of the ratio of operating income to total assets over the past ten years. The post-1993 dummy takes the value of one if the firm issued equity during the 1993 to 2002 period, and zero otherwise. Tobin's q is the ratio of the sum of the book value of debt and the market value of equity to total assets. The dummy for poor operating performance of the main bank (issuing firm) takes the value of one if the ratio of operating income to total assets for the main bank (issuing firm) is smaller than the sample $25^{\text {th }}$ quartile, and zero otherwise. The dummy for poor previous 1 -year excess returns of the main bank takes the value of one if the previous 1-year excess return for the main bank is smaller than the sample $25^{\text {th }}$ quartile, and zero otherwise. The dummy for a high standard deviation of main bank operating income takes the value of one if the standard deviation of operating income for the main bank is higher than the sample $75^{\text {th }}$ quartile, and zero otherwise. The dummy for low main bank Tobin's $\mathrm{q}$ takes the value of one if Tobin's q of the main bank is smaller than the sample $25^{\text {th }}$ quartile, and zero otherwise. The $t$-statistics are in parentheses. $* * *, * *$, and $*$ denote significance at the $0.01,0.5$, and 0.10 levels, respectively.

\begin{tabular}{|c|c|c|c|c|c|c|c|c|}
\hline \multicolumn{9}{|l|}{ Panel A: Full period (1983-2002) } \\
\hline & \multicolumn{4}{|c|}{ Full sample } & \multicolumn{4}{|c|}{ Subsample with main banks } \\
\hline & (1) & (2) & (3) & (4) & (5) & $(6)$ & $(7)$ & (8) \\
\hline \multicolumn{9}{|l|}{ Issuer / issue characteristics } \\
\hline Total bank loans / total debt & $\begin{array}{l}0.06^{* * *} \\
(2.65)\end{array}$ & & & & & & & \\
\hline $\begin{array}{l}\text { Short-term bank loans / } \\
\text { total debt }\end{array}$ & & $\begin{array}{l}0.180^{* *} \\
(5.65)\end{array}$ & & & & & & \\
\hline $\begin{array}{l}\text { Long-term bank loans / } \\
\text { total debt }\end{array}$ & & $\begin{array}{r}-0.082^{*} \\
(2.33)\end{array}$ & & & & & & \\
\hline $\begin{array}{l}\text { Short-term loans from the main } \\
\text { bank / total debt }\end{array}$ & & & $\begin{array}{l}0.226^{* *} \\
(2.41)\end{array}$ & $\begin{array}{l}0.176^{*} \\
(1.82)\end{array}$ & $\begin{array}{l}0.281^{* *} \\
(2.77)\end{array}$ & $\begin{array}{l}0.299^{* *} \\
(2.98)\end{array}$ & $\begin{array}{l}0.269^{* * *} \\
(2.66)\end{array}$ & $\begin{array}{l}0.283^{* * *} \\
(2.81)\end{array}$ \\
\hline $\begin{array}{l}\text { Long-term loans from the main } \\
\text { bank / total debt }\end{array}$ & & & $\begin{array}{c}-0.297^{* *} \\
(2.71)\end{array}$ & $\begin{array}{c}-0.322^{* *} \\
(2.80)\end{array}$ & $\begin{array}{c}-0.229^{*} \\
(1.87)\end{array}$ & $\begin{array}{l}-0.244^{* *} \\
(2.01)\end{array}$ & $\begin{array}{c}-0.249^{* *} \\
(2.02)\end{array}$ & $\begin{array}{l}-0.246^{* *} \\
(2.02)\end{array}$ \\
\hline $\begin{array}{l}\text { Short-term loans from other } \\
\text { banks / total debt }\end{array}$ & & & $\begin{array}{l}-0.027 \\
(0.54)\end{array}$ & $\begin{array}{l}-0.046 \\
(0.75)\end{array}$ & $\begin{array}{l}0.013 \\
(0.23)\end{array}$ & $\begin{array}{l}0.021 \\
(0.38)\end{array}$ & $\begin{array}{l}0.010 \\
(0.19)\end{array}$ & $\begin{array}{l}-0.008 \\
(0.14)\end{array}$ \\
\hline $\begin{array}{l}\text { Long-term loans from other } \\
\text { banks / total debt }\end{array}$ & & & $\begin{array}{l}0.024 \\
(0.32)\end{array}$ & $\begin{array}{l}-0.016 \\
(0.21)\end{array}$ & $\begin{array}{l}-0.010 \\
(0.13)\end{array}$ & $\begin{array}{l}-0.013 \\
(0.16)\end{array}$ & $\begin{array}{r}-0.003 \\
(0.04)\end{array}$ & $\begin{array}{l}-0.004 \\
(0.05)\end{array}$ \\
\hline Keiretsu dummy & & & & $\begin{array}{l}0.019 \\
(1.56)\end{array}$ & $\begin{array}{l}0.020 \\
(1.10)\end{array}$ & $\begin{array}{l}0.016 \\
(1.19)\end{array}$ & $\begin{array}{l}0.020 \\
(1.53)\end{array}$ & $\begin{array}{l}0.018 \\
(1.43)\end{array}$ \\
\hline Log (market value of equity) & & & & $\begin{array}{l}-0.004 \\
(0.76)\end{array}$ & $\begin{array}{l}0.000 \\
(0.03)\end{array}$ & $\begin{array}{l}0.000 \\
(0.05)\end{array}$ & $\begin{array}{l}-0.001 \\
(0.10)\end{array}$ & $\begin{array}{l}0.000 \\
(0.03)\end{array}$ \\
\hline Operating income / total assets & & & & $\begin{array}{l}-0.268 \\
(1.55)\end{array}$ & & & & \\
\hline Poor operating income dummy & & & & & $\begin{array}{l}-0.003 \\
(0.21)\end{array}$ & $\begin{array}{l}-0.013 \\
(0.96)\end{array}$ & $\begin{array}{l}0.006 \\
(0.27)\end{array}$ & $\begin{array}{l}-0.008 \\
(0.61)\end{array}$ \\
\hline Post-1993 dummy & & & & $\begin{array}{l}-0.001 \\
(0.07)\end{array}$ & $\begin{array}{l}-0.005 \\
(0.24)\end{array}$ & $\begin{array}{l}0.001 \\
(0.09)\end{array}$ & $\begin{array}{l}0.003 \\
(0.23)\end{array}$ & $\begin{array}{l}0.003 \\
(0.20)\end{array}$ \\
\hline $\begin{array}{l}\text { Issue amount / market value of } \\
\text { equity }\end{array}$ & & & & $\begin{array}{l}0.101 \\
(1.03)\end{array}$ & $\begin{array}{l}0.114 \\
(1.10)\end{array}$ & $\begin{array}{l}0.126 \\
(1.22)\end{array}$ & $\begin{array}{l}0.121 \\
(1.16)\end{array}$ & $\begin{array}{l}0.115 \\
(1.10)\end{array}$ \\
\hline Tobin's q & & & & $\begin{array}{l}-0.001 \\
(0.30)\end{array}$ & $\begin{array}{l}-0.007 \\
(1.25)\end{array}$ & $\begin{array}{l}-0.006 \\
(1.08)\end{array}$ & $\begin{array}{l}-0.007 \\
(1.25)\end{array}$ & $\begin{array}{l}-0.007 \\
(1.27)\end{array}$ \\
\hline $\begin{array}{l}\text { Equity ownership by financial } \\
\text { institutions }\end{array}$ & & & & $\begin{array}{r}-0.070^{*} \\
(1.66)\end{array}$ & $\begin{array}{r}-0.015 \\
(0.33)\end{array}$ & $\begin{array}{l}-0.008 \\
(0.16)\end{array}$ & $\begin{array}{l}-0.016 \\
(0.34)\end{array}$ & $\begin{array}{l}-0.014 \\
(0.29)\end{array}$ \\
\hline
\end{tabular}


Equity ownership by other corporations

Equity ownership by foreigners

Main bank performance (dummy)

Poor operating performance

Poor previous 1-year excess

returns

High standard deviation of

operating income

Low Tobin's q

Main bank performance * issuer performance (dummy)

Poor operating performance (main bank)* poor operating performance (issuing firm)

Poor previous 1-year excess returns (main bank) * poor operating performance (issuing firm)

High standard deviation of operating income (main bank) * poor operating performance (issuing firm)

Low Tobin's q (main bank) * poor operating performance (issuing firm)

Intercept

F-value

Adjusted-R ${ }^{2}$

Sample size

$\begin{array}{lllll}-0.025 & -0.014 & -0.013 & -0.014 & -0.013 \\ (0.83) & (0.43) & (0.23) & (0.41) & (0.36) \\ 0.124 & 0.062 & 0.058 & 0.077 & 0.067 \\ (1.46) & (0.90) & (0.61) & (0.79) & (0.71)\end{array}$

$-0.003 \quad-0.023^{*}$

(0.21) (1.69)

$-0.006$

(0.51)

$-0.008$

$(0.61)$

0.024

(0.90)

$0.061^{* *}$

(2.41)

$-0.005$

(0.18) 


\begin{tabular}{|c|c|c|c|c|c|c|c|c|c|c|c|c|}
\hline \multicolumn{13}{|l|}{ Panel B: Subperiod } \\
\hline & \multicolumn{6}{|c|}{ Subperiod (1983-1992) } & \multicolumn{6}{|c|}{ Subperiod (1993-2002) } \\
\hline & \multicolumn{2}{|c|}{ Full sample } & \multicolumn{4}{|c|}{ Subsample with main banks } & \multicolumn{2}{|c|}{ Full sample } & \multicolumn{4}{|c|}{ Subsample with main banks } \\
\hline & $(1)$ & $(2)$ & (3) & (4) & $(5)$ & (6) & $(7)$ & $(8)$ & (9) & $(10)$ & $(11)$ & $(12)$ \\
\hline \multicolumn{13}{|l|}{ Issuer / issue characteristics } \\
\hline $\begin{array}{l}\text { Short-term loans from the main bank / } \\
\text { total debt }\end{array}$ & $\begin{array}{l}0.172 \\
(1.55)\end{array}$ & $\begin{array}{l}0.127 \\
(1.06)\end{array}$ & $\begin{array}{l}0.161 \\
(1.30)\end{array}$ & $\begin{array}{l}0.167 \\
(1.36)\end{array}$ & $\begin{array}{l}0.149 \\
(1.21)\end{array}$ & $\begin{array}{l}0.169 \\
(1.39)\end{array}$ & $\begin{array}{c}0.526^{* * *} \\
(2.63)\end{array}$ & $\begin{array}{l}0.451^{* *} \\
(2.17)\end{array}$ & $\begin{array}{l}0.480^{* *} \\
(2.26)\end{array}$ & $\begin{array}{l}0.377^{*} \\
(1.73)\end{array}$ & $\begin{array}{l}0.407^{*} \\
(1.81)\end{array}$ & $\begin{array}{l}0.399^{*} \\
(1.84)\end{array}$ \\
\hline $\begin{array}{l}\text { Long-term loans from the main bank / } \\
\text { total debt }\end{array}$ & $\begin{array}{c}-0.298^{* *} \\
(2.06)\end{array}$ & $\begin{array}{l}-0.211 \\
(1.27)\end{array}$ & $\begin{array}{r}-0.305^{*} \\
(1.69)\end{array}$ & $\begin{array}{r}-0.307^{*} \\
(1.72)\end{array}$ & $\begin{array}{c}-0.311^{*} \\
(1.72)\end{array}$ & $\begin{array}{l}-0.291 \\
(1.63)\end{array}$ & $\begin{array}{r}-0.218 \\
(1.17)\end{array}$ & $\begin{array}{l}-0.142 \\
(0.75)\end{array}$ & $\begin{array}{l}-0.115 \\
(0.64)\end{array}$ & $\begin{array}{l}-0.171 \\
(0.95)\end{array}$ & $\begin{array}{l}-0.115 \\
(0.61)\end{array}$ & $\begin{array}{r}-0.154 \\
(0.85)\end{array}$ \\
\hline $\begin{array}{l}\text { Short-term loans from other banks / total } \\
\text { debt }\end{array}$ & $\begin{array}{l}0.053 \\
(0.91)\end{array}$ & $\begin{array}{l}0.082 \\
(1.28)\end{array}$ & $\begin{array}{l}0.098 \\
(1.49)\end{array}$ & $\begin{array}{l}0.089 \\
(1.34)\end{array}$ & $\begin{array}{l}0.103 \\
(1.56)\end{array}$ & $\begin{array}{l}0.102 \\
(1.56)\end{array}$ & $\begin{array}{l}-0.072 \\
(0.51)\end{array}$ & $\begin{array}{r}-0.050 \\
(0.31)\end{array}$ & $\begin{array}{l}-0.003 \\
(0.02)\end{array}$ & $\begin{array}{l}0.070 \\
(0.39)\end{array}$ & $\begin{array}{l}0.058 \\
(0.32)\end{array}$ & $\begin{array}{l}0.165 \\
(0.86)\end{array}$ \\
\hline $\begin{array}{l}\text { Long-term loans from other banks / total } \\
\text { debt }\end{array}$ & $\begin{array}{l}-0.071 \\
(0.77)\end{array}$ & $\begin{array}{l}-0.104 \\
(1.04)\end{array}$ & $\begin{array}{l}-0.077 \\
(0.74)\end{array}$ & $\begin{array}{r}-0.080 \\
(0.78)\end{array}$ & $\begin{array}{r}-0.069 \\
(0.67)\end{array}$ & $\begin{array}{l}-0.077 \\
(0.75)\end{array}$ & $\begin{array}{l}0.170 \\
(1.25)\end{array}$ & $\begin{array}{l}0.115 \\
(0.76)\end{array}$ & $\begin{array}{l}0.051 \\
(0.34)\end{array}$ & $\begin{array}{l}0.047 \\
(0.30)\end{array}$ & $\begin{array}{l}0.098 \\
(0.62)\end{array}$ & $\begin{array}{l}0.017 \\
(0.11)\end{array}$ \\
\hline Keiretsu dummy & & $\begin{array}{l}0.017 \\
(1.22)\end{array}$ & $\begin{array}{l}0.017 \\
(1.18)\end{array}$ & $\begin{array}{l}0.017 \\
(1.19)\end{array}$ & $\begin{array}{l}0.016 \\
(1.11)\end{array}$ & $\begin{array}{l}0.018 \\
(1.25)\end{array}$ & & $\begin{array}{l}0.010 \\
(0.19)\end{array}$ & $\begin{array}{l}0.018 \\
(0.36)\end{array}$ & $\begin{array}{l}0.007 \\
(0.39)\end{array}$ & $\begin{array}{l}0.014 \\
(0.27)\end{array}$ & $\begin{array}{l}0.006 \\
(0.12)\end{array}$ \\
\hline Log (market value of equity) & & $\begin{array}{l}0.000 \\
(0.07)\end{array}$ & $\begin{array}{l}0.003 \\
(0.47)\end{array}$ & $\begin{array}{l}0.003 \\
(0.45)\end{array}$ & $\begin{array}{l}0.003 \\
(0.43)\end{array}$ & $\begin{array}{l}0.003 \\
(0.44)\end{array}$ & & $\begin{array}{l}0.005 \\
(0.33)\end{array}$ & $\begin{array}{l}0.007 \\
(0.39)\end{array}$ & $\begin{array}{l}0.004 \\
(0.26)\end{array}$ & $\begin{array}{l}0.008 \\
(0.43)\end{array}$ & $\begin{array}{l}0.011 \\
(0.59)\end{array}$ \\
\hline Operating income / total assets & & $\begin{array}{l}0.025 \\
(0.10)\end{array}$ & & & & & & $\begin{array}{l}0.229 \\
(0.52)\end{array}$ & & & & \\
\hline Poor operating income dummy & & & $\begin{array}{l}-0.007 \\
(0.48)\end{array}$ & $\begin{array}{l}-0.017 \\
(1.11)\end{array}$ & $\begin{array}{c}-0.016 \\
(0.60)\end{array}$ & $\begin{array}{l}-0.021 \\
(1.41)\end{array}$ & & & $\begin{array}{c}-0.020 \\
(0.59)\end{array}$ & $\begin{array}{l}-0.009 \\
(0.27)\end{array}$ & $\begin{array}{l}-0.024 \\
(0.68)\end{array}$ & $\begin{array}{r}-0.041 \\
(1.08)\end{array}$ \\
\hline Issue amount / market value of equity & & $\begin{array}{l}0.078 \\
(0.60)\end{array}$ & $\begin{array}{l}0.130 \\
(0.96)\end{array}$ & $\begin{array}{l}0.145 \\
(1.08)\end{array}$ & $\begin{array}{l}0.140 \\
(1.04)\end{array}$ & $\begin{array}{l}0.139 \\
(1.04)\end{array}$ & & $\begin{array}{l}0.411 \\
(1.62)\end{array}$ & $\begin{array}{l}0.237 \\
(0.83)\end{array}$ & $\begin{array}{l}0.482^{*} \\
(1.86)\end{array}$ & $\begin{array}{l}0.240 \\
(0.80)\end{array}$ & $\begin{array}{l}0.369 \\
(1.41)\end{array}$ \\
\hline Tobin's q & & $\begin{array}{l}-0.000 \\
(0.02)\end{array}$ & $\begin{array}{l}-0.002 \\
(0.29)\end{array}$ & $\begin{array}{l}-0.002 \\
(0.24)\end{array}$ & $\begin{array}{c}-0.002 \\
(0.30)\end{array}$ & $\begin{array}{l}-0.002 \\
(0.23)\end{array}$ & & $\begin{array}{r}-0.005 \\
(0.60)\end{array}$ & $\begin{array}{l}-0.003 \\
(0.33)\end{array}$ & $\begin{array}{l}-0.003 \\
(0.38)\end{array}$ & $\begin{array}{l}-0.007 \\
(0.84)\end{array}$ & $\begin{array}{l}-0.008 \\
(0.87)\end{array}$ \\
\hline Equity ownership by financial institutions & & $\begin{array}{l}-0.026 \\
(0.48)\end{array}$ & $\begin{array}{l}-0.033 \\
(0.58)\end{array}$ & $\begin{array}{l}-0.032 \\
(0.56)\end{array}$ & $\begin{array}{l}-0.030 \\
(0.53)\end{array}$ & $\begin{array}{l}-0.020 \\
(0.37)\end{array}$ & & $\begin{array}{c}-0.070 \\
(0.69)\end{array}$ & $\begin{array}{l}-0.067 \\
(0.59)\end{array}$ & $\begin{array}{l}-0.173 \\
(1.53)\end{array}$ & $\begin{array}{l}-0.084 \\
(0.71)\end{array}$ & $\begin{array}{l}-0.169 \\
(1.54)\end{array}$ \\
\hline Equity ownership by other corporations & & $\begin{array}{l}-0.026 \\
(0.69)\end{array}$ & $\begin{array}{r}-0.035 \\
(0.91)\end{array}$ & $\begin{array}{l}-0.034 \\
(0.87)\end{array}$ & $\begin{array}{l}-0.034 \\
(0.87)\end{array}$ & $\begin{array}{l}-0.030 \\
(0.78)\end{array}$ & & $\begin{array}{l}0.033 \\
(0.38)\end{array}$ & $\begin{array}{l}0.022 \\
(0.23)\end{array}$ & $\begin{array}{l}0.007 \\
(0.07)\end{array}$ & $\begin{array}{l}0.018 \\
(0.19)\end{array}$ & $\begin{array}{l}-0.025 \\
(0.25)\end{array}$ \\
\hline Equity ownership by foreigners & & $\begin{array}{l}0.022 \\
(0.28)\end{array}$ & $\begin{array}{l}-0.007 \\
(0.09)\end{array}$ & $\begin{array}{l}-0.003 \\
(0.04)\end{array}$ & $\begin{array}{l}-0.001 \\
(0.01)\end{array}$ & $\begin{array}{l}0.001 \\
(0.01)\end{array}$ & & $\begin{array}{r}-0.044 \\
(0.27)\end{array}$ & $\begin{array}{l}0.011 \\
(0.06)\end{array}$ & $\begin{array}{l}0.027 \\
(0.14)\end{array}$ & $\begin{array}{l}0.046 \\
(0.23)\end{array}$ & $\begin{array}{r}-0.037 \\
(0.20)\end{array}$ \\
\hline
\end{tabular}


Main bank performance (dummy)

Poor operating performance

Poor previous 1-year excess returns

High standard deviation of operating

income

Low Tobin's Q

Main bank performance * issuer performance (dummy)

Poor operating performance (main bank) * poor operating performance (issuing firm)

$-0.007$

$(0.43)$

$-0.002$

$(0.13)$

$-0.005$

$(0.30)$

Poor previous 1-year excess returns

(main bank) * poor operating

performance (issuing firm)

High standard deviation of operating

income (main bank)* poor operating

performance (issuing firm)

Low Tobin's q (main bank) * poor

operating performance (issuing firm)

Intercept

F-value

Adjusted-R ${ }^{2}$

Sample size

0.012

$(0.41)$

$0.063^{* *}$

(2.17)

$-0.015$

$(0.24)$

$1.83^{* *}$

0.039

$\begin{array}{cccccc}0.026^{* *} & 0.015 & -0.011 & -0.009 & -0.009 & -0.015 \\ (1.71) & (0.24) & (0.18) & (0.15) & (0.13) & (0.24) \\ 4.11^{* * *} & 1.33 & 1.48 & 1.60^{*} & 1.46 & 1.83^{* *} \\ 0.034 & 0.013 & 0.023 & 0.029 & 0.022 & 0.039 \\ 415 & 407 & 332 & 332 & 332 & 332\end{array}$

$-0.007$

0.030

$(0.92)$

$-0.016$

$(0.28)$

$-0.048$

(1.28)

$-0.047$

(1.43)

$0.152^{*}$

(1.73)

$0.165^{*}$

(1.93)

$0.163^{*}$

(1.77)

$0.001 \quad-0.085$

$(0.05) \quad(0.51)$

$2.37^{*} \quad 2.10^{* *}$

$0.069 \quad 0.043$

$-0.084$

(0.46)

$2.17^{* *}$

0.046

93

86

72

72

72


Table VI

Probit regression of changes in main bank loans on industry- and performance-adjusted discretionary current accruals in the offering year and firm characteristics

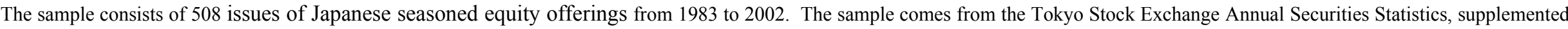

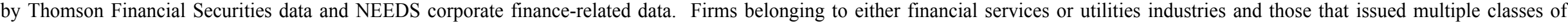

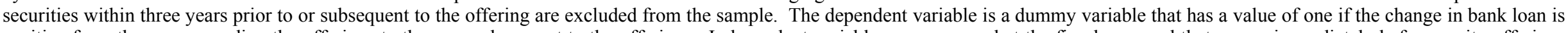

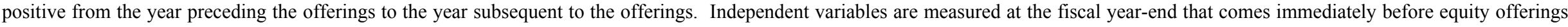

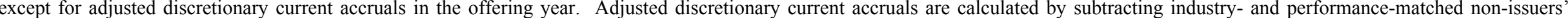

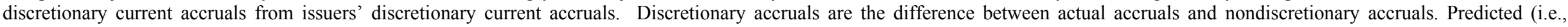

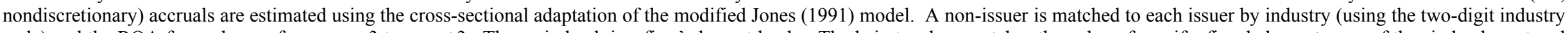

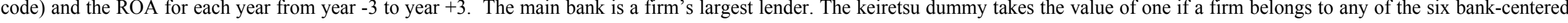

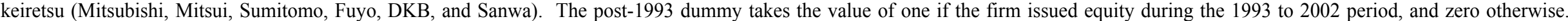

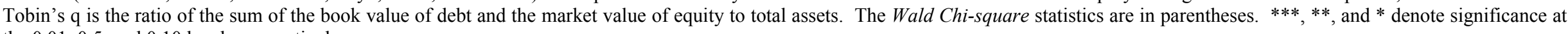
the $0.01,0.5$, and 0.10 levels, respectively.

\begin{tabular}{|c|c|c|c|c|c|c|c|c|c|c|c|c|}
\hline & \multicolumn{6}{|c|}{ Full period (1983-2002) } & \multirow{2}{*}{\multicolumn{3}{|c|}{$\begin{array}{c}\text { Subperiod (1983-1992) } \\
\text { Subsample with main banks }\end{array}$}} & \multirow{2}{*}{\multicolumn{3}{|c|}{$\begin{array}{c}\text { Subperiod (1993-2002) } \\
\text { Subsample with main banks }\end{array}$}} \\
\hline & \multicolumn{3}{|c|}{ Full sample } & \multicolumn{3}{|c|}{ Subsample with main banks } & & & & & & \\
\hline & (1) & (2) & (3) & (4) & (5) & (6) & (7) & (8) & (9) & (10) & (11) & (12) \\
\hline & $\begin{array}{l}\text { Changes in } \\
\text { total bank } \\
\text { loans }\end{array}$ & $\begin{array}{l}\text { Changes } \\
\text { in short- } \\
\text { term bank } \\
\text { loans }\end{array}$ & $\begin{array}{l}\text { Changes in } \\
\text { long-term } \\
\text { bank loans }\end{array}$ & $\begin{array}{l}\text { Changes in } \\
\text { total main } \\
\text { bank loans }\end{array}$ & $\begin{array}{l}\text { Changes } \\
\text { in short- } \\
\text { term main } \\
\text { bank loans }\end{array}$ & $\begin{array}{l}\text { Changes } \\
\text { in long- } \\
\text { term main } \\
\text { bank loans }\end{array}$ & $\begin{array}{l}\text { Changes } \\
\text { in total } \\
\text { main bank } \\
\text { loans }\end{array}$ & $\begin{array}{l}\text { Changes } \\
\text { in short- } \\
\text { term main } \\
\text { bank loans }\end{array}$ & $\begin{array}{l}\text { Changes } \\
\text { in long- } \\
\text { term main } \\
\text { bank loans }\end{array}$ & $\begin{array}{l}\text { Changes } \\
\text { in total } \\
\text { main bank } \\
\text { loans }\end{array}$ & $\begin{array}{l}\text { Changes } \\
\text { in short- } \\
\text { term main } \\
\text { bank loans }\end{array}$ & $\begin{array}{l}\text { Changes } \\
\text { in long- } \\
\text { term main } \\
\text { bank loans }\end{array}$ \\
\hline $\begin{array}{l}\text { Adjusted discretionary } \\
\text { current accruals in the } \\
\text { offering year }\end{array}$ & $\begin{array}{c}-1.376^{* *} \\
(5.00)\end{array}$ & $\begin{array}{c}-1.383^{* *} \\
(5.26)\end{array}$ & $\begin{array}{l}-0.330 \\
(0.26)\end{array}$ & $\begin{array}{l}-0.932 \\
(2.75)\end{array}$ & $\begin{array}{c}-1.477^{*} \\
(3.67)\end{array}$ & $\begin{array}{l}-1.290 \\
(2.54)\end{array}$ & $\begin{array}{l}-0.986 \\
(1.54)\end{array}$ & $\begin{array}{l}-1.106 \\
(1.80)\end{array}$ & $\begin{array}{l}-1.211 \\
(1.89)\end{array}$ & $\begin{array}{l}-0.769 \\
(0.10)\end{array}$ & $\begin{array}{l}-7.018^{* *} \\
(4.57)\end{array}$ & $\begin{array}{l}3.356 \\
(1.00)\end{array}$ \\
\hline Total bank loans / total debt & $\begin{array}{l}0.700^{*} \\
(3.58)\end{array}$ & & & & & & & & & & & \\
\hline $\begin{array}{l}\text { Short-term bank loans / } \\
\text { total debt } \\
\text { Long-term bank loans / } \\
\text { total debt }\end{array}$ & & $\begin{array}{l}0.391 \\
(0.60) \\
0.914^{*} \\
(2.84)\end{array}$ & $\begin{array}{c}1.889^{* * *} \\
(12.26) \\
0.714 \\
(1.55)\end{array}$ & & & & & & & & & \\
\hline $\begin{array}{l}\text { Loans from the main bank / } \\
\text { total debt }\end{array}$ & & & & $\begin{array}{c}-3.975^{* * *} \\
(8.47)\end{array}$ & & & $\begin{array}{l}-4.264^{* *} \\
(6.39)\end{array}$ & & & $\begin{array}{l}-4.943^{*} \\
(3.34)\end{array}$ & & \\
\hline $\begin{array}{l}\text { Short-term loans from the } \\
\text { main bank / total debt }\end{array}$ & & & & & $\begin{array}{l}-3.792^{* *} \\
(4.61)\end{array}$ & $\begin{array}{c}-0.034 \\
(0.00)\end{array}$ & & $\begin{array}{l}-5.292^{* *} \\
(5.93)\end{array}$ & $\begin{array}{l}1.119 \\
(0.38)\end{array}$ & & $\begin{array}{l}-2.366 \\
(0.26)\end{array}$ & $\begin{array}{l}-5.135 \\
(1.86)\end{array}$ \\
\hline $\begin{array}{l}\text { Long-term loans from the } \\
\text { main bank / total debt }\end{array}$ & & & & & $\begin{array}{l}-0.241 \\
(0.02)\end{array}$ & $\begin{array}{l}2.022^{*} \\
(3.27)\end{array}$ & & $\begin{array}{l}-1.059 \\
(0.20)\end{array}$ & $\begin{array}{l}1.800 \\
(0.57)\end{array}$ & & $\begin{array}{l}4.882 \\
(1.04)\end{array}$ & $\begin{array}{l}-5.610 \\
(2.04)\end{array}$ \\
\hline $\begin{array}{l}\text { Loans from other banks / } \\
\text { total debt }\end{array}$ & & & & $\begin{array}{l}2.496^{* * *} \\
(14.69)\end{array}$ & & & $\begin{array}{l}2.796^{* * *} \\
(14.67)\end{array}$ & & & $\begin{array}{r}1.824 \\
(1.11)\end{array}$ & & \\
\hline Short-term loans from other & & & & & $2.876^{* * *}$ & $1.729^{* *}$ & & $2.632^{* * *}$ & $1.684^{*}$ & & $9.279^{* *}$ & $5.533^{*}$ \\
\hline
\end{tabular}




\begin{tabular}{|c|c|c|c|c|c|c|c|c|c|c|c|c|}
\hline banks / total debt & & & & & $(10.88)$ & $(3.91)$ & & $(7.54)$ & $(3.08)$ & & $(5.94)$ & $(3.24)$ \\
\hline $\begin{array}{l}\text { Long-term loans from other } \\
\text { banks / total debt }\end{array}$ & & & & & $\begin{array}{l}1.402 \\
(1.60)\end{array}$ & $\begin{array}{l}2.022^{*} \\
(3.27)\end{array}$ & & $\begin{array}{c}2.878^{* *} \\
(4.83)\end{array}$ & $\begin{array}{l}1.649 \\
(1.54)\end{array}$ & & $\begin{array}{l}-3.888 \\
(0.92)\end{array}$ & $\begin{array}{l}4.329 \\
(1.98)\end{array}$ \\
\hline Keiretsu dummy & $\begin{array}{l}0.031 \\
(0.31)\end{array}$ & $\begin{array}{l}0.101 \\
(0.36)\end{array}$ & $\begin{array}{l}0.276 \\
(2.34)\end{array}$ & $\begin{array}{l}0.101 \\
(0.31)\end{array}$ & $\begin{array}{l}0.161 \\
(0.78)\end{array}$ & $\begin{array}{l}0.075 \\
(0.15)\end{array}$ & $\begin{array}{l}0.151 \\
(0.62)\end{array}$ & $\begin{array}{l}0.195 \\
(1.00)\end{array}$ & $\begin{array}{l}0.164 \\
(0.39)\end{array}$ & $\begin{array}{l}-1.421 \\
(1.99)\end{array}$ & $\begin{array}{l}-0.276 \\
(0.10)\end{array}$ & $\begin{array}{l}-8.595 \\
(0.11)\end{array}$ \\
\hline $\log$ (market value of equity) & $\begin{array}{l}-0.068 \\
(0.93)\end{array}$ & $\begin{array}{c}-0.130^{*} \\
(3.51)\end{array}$ & $\begin{array}{l}-0.015 \\
(0.04)\end{array}$ & $\begin{array}{l}-0.028 \\
(0.14)\end{array}$ & $\begin{array}{l}-0.078 \\
(0.99)\end{array}$ & $\begin{array}{l}0.067 \\
(0.70)\end{array}$ & $\begin{array}{l}-0.024 \\
(0.08)\end{array}$ & $\begin{array}{l}-0.101 \\
(1.42)\end{array}$ & $\begin{array}{l}0.095 \\
(1.20)\end{array}$ & $\begin{array}{l}-0.303 \\
(1.03)\end{array}$ & $\begin{array}{l}0.066 \\
(0.03)\end{array}$ & $\begin{array}{l}-6.149 \\
(0.32)\end{array}$ \\
\hline $\begin{array}{l}\text { Operating income / total } \\
\text { assets }\end{array}$ & $\begin{array}{l}-8.402^{* * *} \\
(8.19)\end{array}$ & $\begin{array}{l}-7.753^{* * *} \\
(7.76)\end{array}$ & $\begin{array}{r}-3.375 \\
(1.42)\end{array}$ & $\begin{array}{l}-4.003 \\
(1.41)\end{array}$ & $\begin{array}{l}-3.996 \\
(1.33)\end{array}$ & $\begin{array}{l}-2.850 \\
(0.65)\end{array}$ & $\begin{array}{r}-5.125 \\
(1.78)\end{array}$ & $\begin{array}{l}-5.425 \\
(1.90)\end{array}$ & $\begin{array}{l}-2.529 \\
(0.40)\end{array}$ & $\begin{array}{l}1.416 \\
(0.03)\end{array}$ & $\begin{array}{l}8.276 \\
(0.58)\end{array}$ & $\begin{array}{l}0.600 \\
(1.16)\end{array}$ \\
\hline Post-1993 dummy & $\begin{array}{l}-0.217 \\
(1.42)\end{array}$ & $\begin{array}{c}-0.511^{* * *} \\
(7.60)\end{array}$ & $\begin{array}{l}0.152 \\
(0.63)\end{array}$ & $\begin{array}{l}-0.156 \\
(0.56)\end{array}$ & $\begin{array}{c}-0.429^{*} \\
(3.72)\end{array}$ & $\begin{array}{l}0.018 \\
(0.01)\end{array}$ & & & & & & \\
\hline $\begin{array}{l}\text { Issue amount / market value } \\
\text { of equity }\end{array}$ & $\begin{array}{c}-2.447^{*} \\
(2.87)\end{array}$ & $\begin{array}{l}-0.018 \\
(0.00)\end{array}$ & $\begin{array}{c}-4.084^{* * *} \\
(6.76)\end{array}$ & $\begin{array}{l}-1.247 \\
(0.65)\end{array}$ & $\begin{array}{l}0.026 \\
(0.00)\end{array}$ & $\begin{array}{l}-2.863^{*} \\
(3.07)\end{array}$ & $\begin{array}{l}-0.231 \\
(0.02)\end{array}$ & $\begin{array}{l}-0.229 \\
(0.02)\end{array}$ & $\begin{array}{r}-1.129 \\
(0.39)\end{array}$ & $\begin{array}{l}-7.920^{*} \\
(3.30)\end{array}$ & $\begin{array}{l}-0.585 \\
(0.01)\end{array}$ & $\begin{array}{c}22.476^{-} \\
(10.43 \\
)\end{array}$ \\
\hline Tobin's q & $\begin{array}{c}0.014^{* *} \\
(0.04)\end{array}$ & $\begin{array}{l}0.024 \\
(0.11)\end{array}$ & $\begin{array}{l}-0.070 \\
(0.77)\end{array}$ & $\begin{array}{l}-0.041 \\
(0.22)\end{array}$ & $\begin{array}{c}-0.066 \\
(0.49)\end{array}$ & $\begin{array}{l}-0.055 \\
(0.35)\end{array}$ & $\begin{array}{l}0.014 \\
(0.01)\end{array}$ & $\begin{array}{r}-0.017 \\
(0.02)\end{array}$ & $\begin{array}{r}-0.010 \\
(0.01)\end{array}$ & $\begin{array}{l}-0.142 \\
(0.03)\end{array}$ & $\begin{array}{l}-0.291 \\
(0.91)\end{array}$ & $\begin{array}{l}-0.232 \\
(0.99)\end{array}$ \\
\hline $\begin{array}{l}\text { Equity ownership by } \\
\text { financial institutions }\end{array}$ & $\begin{array}{l}0.009 \\
(0.00)\end{array}$ & $\begin{array}{l}0.252 \\
(0.18)\end{array}$ & $\begin{array}{l}-0.829 \\
(1.53)\end{array}$ & $\begin{array}{l}-0.548 \\
(0.66)\end{array}$ & $\begin{array}{l}-0.099 \\
(0.02)\end{array}$ & $\begin{array}{l}0.000 \\
(0.00)\end{array}$ & $\begin{array}{l}-0.686 \\
(0.79)\end{array}$ & $\begin{array}{l}-0.535 \\
(0.48)\end{array}$ & $\begin{array}{l}0.203 \\
(0.06)\end{array}$ & $\begin{array}{l}-0.084 \\
(0.00)\end{array}$ & $\begin{array}{l}1.829 \\
(0.65)\end{array}$ & $\begin{array}{l}1.187 \\
(0.27)\end{array}$ \\
\hline $\begin{array}{l}\text { Equity ownership by other } \\
\text { corporations }\end{array}$ & $\begin{array}{l}0.035 \\
(0.01)\end{array}$ & $\begin{array}{l}-0.124 \\
(0.08)\end{array}$ & $\begin{array}{l}-0.207 \\
(0.20)\end{array}$ & $\begin{array}{l}-0.268 \\
(0.33)\end{array}$ & $\begin{array}{l}0.020 \\
(0.00)\end{array}$ & $\begin{array}{l}0.320 \\
(0.40)\end{array}$ & $\begin{array}{l}-0.485 \\
(0.84)\end{array}$ & $\begin{array}{l}-0.298 \\
(0.31)\end{array}$ & $\begin{array}{l}0.507 \\
(0.77)\end{array}$ & $\begin{array}{l}2.310 \\
(2.19)\end{array}$ & $\begin{array}{l}2.878 \\
(2.27)\end{array}$ & $\begin{array}{l}0.924 \\
(0.27)\end{array}$ \\
\hline $\begin{array}{l}\text { Equity ownership by } \\
\text { foreigners }\end{array}$ & $\begin{array}{l}0.271 \\
(0.05)\end{array}$ & $\begin{array}{l}1.624 \\
(1.80)\end{array}$ & $\begin{array}{r}-1.443 \\
(1.07)\end{array}$ & $\begin{array}{l}1.145 \\
(1.29)\end{array}$ & $\begin{array}{l}1.090 \\
(1.13)\end{array}$ & $\begin{array}{l}0.468 \\
(0.19)\end{array}$ & $\begin{array}{l}1.708 \\
(2.26)\end{array}$ & $\begin{array}{l}1.059 \\
(0.90)\end{array}$ & $\begin{array}{l}0.508 \\
(0.19)\end{array}$ & $\begin{array}{l}-1.859 \\
(0.37)\end{array}$ & $\begin{array}{l}-2.112 \\
(0.34)\end{array}$ & $\begin{array}{l}0.503 \\
(0.02)\end{array}$ \\
\hline Intercept & $\begin{array}{l}0.351 \\
(0.23)\end{array}$ & $\begin{array}{l}0.895 \\
(1.61)\end{array}$ & $\begin{array}{l}-0.227 \\
(0.09)\end{array}$ & $\begin{array}{l}0.250 \\
(0.10)\end{array}$ & $\begin{array}{l}0.407 \\
(0.26)\end{array}$ & $\begin{array}{c}-1.509^{*} \\
(3.21)\end{array}$ & $\begin{array}{l}0.075 \\
(0.01)\end{array}$ & $\begin{array}{l}0.871 \\
(1.02)\end{array}$ & $\begin{array}{c}-2.245^{* *} \\
(6.11)\end{array}$ & $\begin{array}{l}3.163 \\
(1.10)\end{array}$ & $\begin{array}{l}-2.831 \\
(0.57)\end{array}$ & $\begin{array}{l}4.228 \\
(1.40)\end{array}$ \\
\hline Mean of dependent variable & 0.244 & 0.299 & 0.191 & 0.345 & 0.344 & 0.249 & 0.359 & 0.367 & 0.249 & 0.267 & 0.214 & 0.250 \\
\hline $\begin{array}{l}\text { Likelihood ratio (Chi- } \\
\text { square) }\end{array}$ & 29.92 & 35.71 & 38.88 & 27.01 & 33.94 & 23.52 & 25.27 & 30.62 & 21.04 & 12.27 & 16.26 & 7.01 \\
\hline Sample size & 493 & 493 & 493 & 391 & 391 & 391 & 321 & 321 & 321 & 70 & 70 & 70 \\
\hline
\end{tabular}




\section{Table VII}

Cumulative abnormal returns (CARs) around the announcement of equity offerings

The sample consists of 508 issues of Japanese seasoned equity offerings from 1983 to 2002 . The sample comes from the Tokyo Stock Exchange Annual Securities Statistics, supplemented by Thomson Financial Securities data and NEEDS corporate finance-related data. Firms belonging to either financial services or utilities industries and those that issued multiple classes of securities within three years prior to or subsequent to the offering are excluded from the sample. Abnormal returns for announcing firms are computed using two different approaches. First, for each issue announcement, the daily abnormal returns are calculated using a standard event study methodology. Market model estimates are measured by using 200 trading days of returns data, beginning 220 days before and ending 21 days before the issue announcement. The benchmark market return is the PACAP equally weighted market return. Daily abnormal returns are cumulated to obtain a CAR from day $-t$ before the issue announcement to day $+t$ after the issue announcement. Second, abnormal returns are computed as the difference in returns between the sample firm and a growth-matched firm that is chosen based on the growth rate of sales. AD denotes announcement date. $* * *, * *$, and $*$ denote significance at the $0.01,0.5$, and 0.10 levels, respectively.

\begin{tabular}{lcccc}
\hline \multirow{2}{*}{ Event windows } & \multicolumn{2}{c}{ Market model } & \multicolumn{2}{c}{ Growth-matched firm } \\
\cline { 2 - 5 } & Mean & Median & Mean & Median \\
\hline (AD-1) & $0.219^{*}$ & -0.030 & 0.152 & 0.136 \\
$(\mathrm{AD})$ & $0.405^{* * *}$ & 0.025 & $0.688^{* * *}$ & $0.520^{* *}$ \\
$(\mathrm{AD}+1)$ & 0.169 & -0.187 & $0.396^{*}$ & $0.261^{* *}$ \\
$(\mathrm{AD}-1, \mathrm{AD})$ & $0.624^{* *}$ & 0.147 & $0.840^{* * *}$ & $0.722^{* * *}$ \\
$(\mathrm{AD}-1, \mathrm{AD}+1)$ & $0.793^{* *}$ & 0.419 & $1.236^{* * *}$ & $1.110^{* * *}$ \\
\hline
\end{tabular}


Table VIII

Multivariate regression of three-day equity announcement returns $[C A R(-1,1)]$ on industry- and performance-adjusted discretionary current accruals in the offering year

The sample consists of 508 issues of Japanese seasoned equity offerings from 1983 to 2002 . The sample comes from the Tokyo Stock Exchange Annual Securities Statistics, supplemented by Thomson Financial Securities data and NEEDS corporate finance-related data. Firms belonging to either financial services or utilities industries and those that issued multiple classes of securities within three years prior to or subsequent to the offering are excluded from the sample. The dependent variable is the CAR $(-1,1)$. Abnormal returns are computed as the difference in returns between the sample firm and a growth-matched firm that is chosen based on the growth rate of sales. Independent variables are measured at the fiscal year-end that comes immediately before equity offerings except for adjusted discretionary current accruals in the offering year. Adjusted discretionary current accruals are calculated by subtracting industry- and performance-matched non-issuers' discretionary current accruals from issuers' discretionary current accruals. Discretionary accruals are the difference between actual accruals and nondiscretionary accruals. Predicted (i.e., nondiscretionary) accruals are estimated using the cross-sectional adaptation of the modified Jones (1991) model. A non-issuer is matched to each issuer by industry (using the two-digit industry code) and the ROA for each year from year -3 to year +3 . The main bank is a firm's largest lender. The post-1993 dummy takes the value of one if the firm issued equity during the 1993 to 2002 period, and zero otherwise. Tobin's q is the ratio of the sum of the book value of debt and the market value of equity to total assets. The $t$-statistics are in parentheses. $* * *, * *$, and $*$ denote significance at the $0.01,0.5$, and 0.10 levels, respectively.

\begin{tabular}{|c|c|c|c|c|}
\hline & & Full sampl & & $\begin{array}{c}\text { Subsample } \\
\text { with main banks }\end{array}$ \\
\hline & $(1)$ & $(2)$ & (3) & (4) \\
\hline $\begin{array}{l}\text { Adjusted discretionary current accruals in the } \\
\text { offering year }\end{array}$ & $\begin{array}{l}0.030 \\
(1.45)\end{array}$ & $\begin{array}{l}0.030 \\
(1.45)\end{array}$ & $\begin{array}{l}0.030 \\
(1.28)\end{array}$ & $\begin{array}{l}0.042 \\
(1.52)\end{array}$ \\
\hline $\begin{array}{l}\text { Short-term loans from the main bank / total } \\
\text { debt }\end{array}$ & & & $\begin{array}{l}0.018 \\
(0.36)\end{array}$ & $\begin{array}{l}-0.027 \\
(0.50)\end{array}$ \\
\hline $\begin{array}{l}\text { Long-term loans from the main bank / total } \\
\text { debt }\end{array}$ & & & $\begin{array}{r}-0.040 \\
(0.67)\end{array}$ & $\begin{array}{l}-0.077 \\
(1.16)\end{array}$ \\
\hline Short-term loans from other banks / total debt & & & $\begin{array}{l}-0.044 \\
(1.57)\end{array}$ & $\begin{array}{c}-0.050^{*} \\
(1.68)\end{array}$ \\
\hline Long-term loans from other banks / total debt & & & $\begin{array}{l}0.021 \\
(0.52)\end{array}$ & $\begin{array}{l}0.010 \\
(0.23)\end{array}$ \\
\hline $\begin{array}{l}\text { Individual stock returns in the previous year } \\
\text { before the offering announcement }\end{array}$ & & $\begin{array}{l}-0.016^{* * *} \\
(2.99)\end{array}$ & $\begin{array}{c}-0.011^{*} \\
(1.90)\end{array}$ & $\begin{array}{c}-0.014^{* *} \\
(2.01)\end{array}$ \\
\hline $\begin{array}{l}\text { Market returns in the previous year before the } \\
\text { offering announcement }\end{array}$ & & $\begin{array}{l}0.075^{* * *} \\
(5.61)\end{array}$ & $\begin{array}{l}0.061^{* * *} \\
(3.86)\end{array}$ & $\begin{array}{l}0.052^{* * *} \\
(2.99)\end{array}$ \\
\hline Keiretsu dummy & & & $\begin{array}{l}-0.006 \\
(1.01)\end{array}$ & $\begin{array}{l}-0.007 \\
(0.97)\end{array}$ \\
\hline Log (market value of equity) & & & $\begin{array}{l}-0.001 \\
(0.38)\end{array}$ & $\begin{array}{l}-0.001 \\
(0.38)\end{array}$ \\
\hline Operating income / total assets & & & $\begin{array}{l}-0.065 \\
(0.73)\end{array}$ & $\begin{array}{l}-0.094 \\
(0.79)\end{array}$ \\
\hline Post-1993 dummy & & & $\begin{array}{l}-0.011 \\
(1.51)\end{array}$ & $\begin{array}{l}0.001 \\
(0.14)\end{array}$ \\
\hline Issue amount / market value of equity & & $\begin{array}{l}0.092^{* *} \\
(1.98)\end{array}$ & $\begin{array}{l}0.055 \\
(1.10)\end{array}$ & $\begin{array}{l}0.056 \\
(1.00)\end{array}$ \\
\hline Tobin's q & & & $\begin{array}{l}-0.001 \\
(0.21)\end{array}$ & $\begin{array}{l}-0.001 \\
(0.20)\end{array}$ \\
\hline Equity ownership by financial institutions & & & $\begin{array}{l}-0.016 \\
(0.72)\end{array}$ & $\begin{array}{c}-0.042^{*} \\
(1.61)\end{array}$ \\
\hline Equity ownership by other corporations & & & $\begin{array}{l}0.025 \\
(1.59)\end{array}$ & $\begin{array}{l}0.002 \\
(0.10)\end{array}$ \\
\hline Equity ownership by foreigners & & & $\begin{array}{l}0.019 \\
(0.43)\end{array}$ & $\begin{array}{l}-0.034 \\
(0.66)\end{array}$ \\
\hline Intercept & $\begin{array}{c}0.007^{* * *} \\
(3.08)\end{array}$ & $\begin{array}{c}-0.017^{* * *} \\
(2.82)\end{array}$ & $\begin{array}{l}0.005 \\
(0.18)\end{array}$ & $\begin{array}{l}0.033 \\
(1.09)\end{array}$ \\
\hline F-value & 2.09 & $10.02^{* * *}$ & $2.99^{* * *}$ & $1.95^{* *}$ \\
\hline Adjusted- $\mathrm{R}^{2}$ & 0.002 & 0.067 & 0.061 & 0.037 \\
\hline Sample size & 508 & 508 & 493 & 404 \\
\hline
\end{tabular}


Table IX

Adjusted discretionary current accruals in the offering year by regulatory rules

The sample consists of 431 issues of Japanese seasoned equity offerings from 1983 to March 1996. The sample comes from the Tokyo Stock Exchange Annual Securities Statistics, supplemented by Thomson Financial Securities data and NEEDS corporate finance-related data. Firms belonging to either financial services or utilities industries and those that issued multiple classes of securities within three years prior to or subsequent to the offering are excluded from the sample. Adjusted discretionary current accruals are calculated by subtracting industry- and performance-matched non-issuers' discretionary current accruals from issuers' discretionary current accruals. Discretionary accruals are the difference between actual accruals and nondiscretionary accruals. Predicted (i.e., nondiscretionary) accruals are estimated using the cross-sectional adaptation of the modified Jones (1991) model. A non-issuer is matched to each issuer by industry (using the two-digit industry code) and the ROA for each year from year -3 to year +3 . $p$-values are in parentheses. $* * *, * *$, and $*$ denote significance at the $0.01,0.5$, and 0.10 levels, respectively.

Panel A: By profits per share prior to public equity offerings

\begin{tabular}{lclc}
\hline & $\begin{array}{l}\text { Firm's after-tax ordinary profits in the } \\
\text { previous year are smaller than 10 yen } \\
\text { per share }(\mathrm{n}=17)\end{array}$ & $\begin{array}{l}\text { Firm's after-tax ordinary profits in } \\
\text { the previous year are equal to or } \\
\text { greater than 10 yen per share } \\
(\mathrm{n}=414)\end{array}$ & $\begin{array}{l}p \text {-value of } \\
\text { difference }\end{array}$ \\
\hline \multirow{2}{*}{ Mean } & $\begin{array}{c}0.047^{* *} \\
(0.013)\end{array}$ & $0.023^{* *}$ & 0.199 \\
Median & $0.040^{* *}$ & $0.023)$ & $0.022^{* * *}$ \\
& $(0.049)$ & $(0.000)$ & 0.194 \\
\hline
\end{tabular}

Panel B: By profit changes after public equity offerings

\begin{tabular}{lccc}
\hline & $\begin{array}{l}\text { The difference in after-tax ordinary } \\
\text { profits before and after equity } \\
\text { offerings is negative }(\mathrm{n}=226)\end{array}$ & $\begin{array}{l}\text { The difference in after-tax ordinary } \\
\text { profits before and after equity } \\
\text { offerings is positive }(\mathrm{n}=200)\end{array}$ & $\begin{array}{c}p \text {-value of } \\
\text { difference }\end{array}$ \\
\hline \multirow{3}{*}{ Mean } & $\begin{array}{l}0.026^{* * *} \\
(0.000)\end{array}$ & $0.022^{* * *}$ & 0.678 \\
& $0.024^{* * *}$ & $0.01)$ & $0.023^{* * *}$ \\
Median & $(0.000)$ & $(0.006)$ & \\
\hline
\end{tabular}




\section{Appendix Method for Measuring Discretionary Current Accruals}

Dechow, Sloan, and Sweeney (1995) and Kothari, Leone, and Wasley (2004) demonstrate that the modified Jones (1991) model performs best among the various discretionary accruals models. This model has been adopted by many studies, including Teoh, Welch, and Wong (1998), among others. Following these studies, for each year in the test period we measure the coefficients of the current accrual models by estimating the following regressions for non-issuers who operate in the same industry as the issuers (to the first two digits of the industry code used in the PACAP Research Center database): ${ }^{21}$

$$
C A C_{i t} / T A_{i t-1}=\beta_{0} / T A_{i t-1}+\beta_{1}\left(\Delta R E V_{i t}-\Delta R E C_{i t}\right) / T A_{i t-1}+\varepsilon_{i t},
$$

where $\mathrm{CAC}_{\mathrm{it}}$ represents current accruals in year $t$ for firm $i ;{ }^{22} \mathrm{TA}_{\mathrm{it}-1}$ represents total assets (PACAP BAL \#9) in year $t-1$ for firm $i$; $\Delta \mathrm{REV}_{\text {it }}$ represents revenues (PACAP INC \#1) in year $t$ less revenues in year $t-1$ for firm $i$ (i.e., change in revenues); and $\triangle \mathrm{REC}_{\mathrm{it}}$ represents receivables (PACAP BAL \#3) in year $t$ less receivables in year $t-1$ for firm $i$ (i.e., change in receivables). We scale all variables in regression (a1) by total assets in year $t-1$ to reduce potential heteroskedasticity. This cross-sectional regression is reestimated for each year and industry.

We then compute nondiscretionary current accruals (NDCAC) for the sample firms as follows:

$$
N D C A C_{j t}=b_{0} / T A_{j t-1}+b_{1}\left(\Delta R E V_{j t}-\Delta R E C_{j t}\right) / T A_{j t-1},
$$

\footnotetext{
${ }^{21}$ Following previous research (e.g., Jones (1991), Gaver, Gaver, and Austin (1995), Sloan (1996)), we estimate current accruals in year $t$ as the change in current assets (PACAP BAL \#6) other than cash (PACAP BAL \#1) and short-term investments (PACAP BAL \#2) in two consecutive years ending in year $t$ less the change in current liabilities (PACAP BAL \#13) other than short-term loans (PACAP BAL \#11, which is the sum of short-term loans payable (JAF \#33), current portion of long-term debt (JAF \#34), and current portion of bonds (JAF \#35)) in two consecutive years ending in year $t$. Total accruals in year $t$ are estimated as current accruals less depreciation, amortization, and depletion (PACAP JAF \#74) in year $t$.

${ }^{22}$ Current accruals are the change in noncash current assets minus the change in operating current liabilities. Specifically, $C A C=\Delta$ (current assets - cash) $-\Delta$ (current liabilities - short-term loans).
} 
where $b_{0}$ and $b_{1}$ are the estimated coefficients from regressions (a1).

Discretionary current accruals (DCAC) are computed as the difference between realized current accruals scaled by the prior year's total assets and NDCAC.

Following Kothari, Leone, and Wasley (2004), we subtract the DCAC for a matching firm from that for an issuer where a non-issuer is matched to each issuer by industry (two-digit industry code) and assetscaled net income (i.e., $\mathrm{ROA}_{\mathrm{it}}$ ). We interpret this matching firm-controlled discretionary accruals estimate as a proxy for accruals manipulation. 